\title{
INTERNATIONAL REVERBERATION TO INCORPORATION OF BALTIC STATES BY SOVIET UNION IN SUMMER 1940 AND LATER
}

\begin{abstract}
Magnus ILMJÄRV
Institute of History of Tallinn University, Rüütli 6, 10130 Tallinn, Estonia; magnus20@mail.ee

So far the published literature on the subject at hand has not sufficiently covered the reaction of foreign states, indeed, of the whole world community to the occupation and the subsequent incorporation of the Baltic states into the Soviet Union at the beginning of the Second World War - in the summer of 1940. Consequently this article attempts to eliminate, at least partly, the described shortcoming in the field of written contemporary history. The first part of the article deals with the Soviet ultimatums to Lithuania, Latvia and Estonia in mid-June 1940, and foreign policy moves undertaken by the so-called "June-governments" (formed and forced into power by the Soviet Union) of these Baltic states. The second part of the work will examine the attitudes and consequent moves, related to the occupation and incorporation of the Baltic states by the Soviet Union, of various foreign states.
\end{abstract}

The Baltic states were occupied in the summer of 1940 by the Soviet Union not by military conquest but by peaceful means. Removing the legal governments of the Baltic states from office by using ultimatums, the Soviet Union violated the mutual assistance pacts concluded between itself and the Baltic states just eight months earlier in the autumn of 1939. Furthermore, the absence of any visible and audible objections to the actions of the Soviet Union by the Baltic people and their governments in 1939, as well as in the summer of 1940, complicated the situation in view of the dictates laid down by international laws. According to the 1907 Hague Conventions Article 42, "occupation" is defined as the conquest of a foreign country or a part of it by the military action only. In the case of the Baltic states the Soviet military units were stationed on the Baltic territories as a result of the concluded, supposedly voluntary, treaty - therefore not by the military but by peaceful means. The 1907 Hague Convention did not touch upon the possibilities of the occupant and occupee agreeing upon introduction and utilization of the occupation 
régime by means of a diplomatic treaty. ${ }^{1}$ Between the two world wars only one type of occupation was recognised: the occupatio bellica or occupation by war. We must stress here that in June 1940, when the Baltic states and their governments reacted to ultimatums, supported by military threats, legitimate governments of the Baltic states and their representatives did not reject the accusations presented in the Soviet ultimatums, but accepted these without any official protest.

\section{FOREIGN POLICIES OF JUNE-GOVERNMENTS}

In addition to the diffidence of all three Baltic states with respect to their relations with the Soviet Union, they also quickly transformed themselves into purveyors of disinformation. Thus the Baltic news media and press, censored and suppressed heavily by their authoritarian régimes, became the intermediary between the government's disinformation and its own citizens, as well as the world at large - in effect a propaganda arm of the régime but also of the Soviet Union. In fact, the public was told that the new situation in the country and region did not mean occupation, while appealing to everybody to view the Red Army as a friendly allied army. Subsequently, the accredited military representatives of all three Baltic countries signed protocols giving the Soviet Union right to occupy sections of land in their territories, thus providing formal legal foundation for the peaceful occupation to follow. With these actions, the true meaning of which was not allowed to reach the public consciousness, thus causing the Baltic régimes to commence their campaigns of disinformation - to blind their own people as well as the rest of the world. The foreign media and radio stations only repeated the statements of the Baltic governments word by word, thereby persistently justifying the aggression of the Soviet Union and the occupation of the Baltic countries. Thus, as expected, the actions and pronouncements of all three Baltic republics and their foreign diplomatic services became the basis on which the world apprised the events in the Baltic States. This in practice meant that the victim was justifying the actions and crimes of its executioner! Soon the occupier of the Baltic states began to utilize its military power, or at least threaten to use it, thereby further restricting the sovereignty of the occupied states. Meanwhile the need for military occupation régime disappeared, because the leftists, and the military officers, and many influential individuals emerged who in most cases supported and agreed to carry out all requests of the Soviet government. Furthermore, the apparent overlords of the region, the Baltic authoritarian regimes, of Kārlis Ulmanis, Konstantin Päts and also Antanas Merkis, collaborated openly and willingly with the Soviet Union.

Apart from the shortcomings of the prevailing international law in defining the concept of "occupation", one should understand that the post-ultimatum political

1 Levie, H. S. The Code of the International Armed Conflict, 2. London; Rome; New York, Oceana Publications, Inc., 1986, 713. 
and administrative actions taking place in the Baltic states did in no way reflect the free will and national interests of the Baltic people, but only those of the occupying power - the Soviet Union.

The declarations published on June 18 by Justas Paleckis' Cabinet of Lithuania, on June 21 by Augusts Kirhenšteins' Cabinet of Latvia and on June 22 by Johannes Vares' Cabinet of Estonia, dealt with the aspects of the foreign policy, emphasizing the need to fulfil the requirements of the mutual assistance pact with the Soviet Union honorably, while calling for the development of sincere and friendly BalticSoviet relationships. The declarations stated that only this approach would ascertain the protection and defense of the countries and the preservation of independence. The declarations further stressed that the government shared people's warm feelings toward the Red Army and offered it all the support it could muster. ${ }^{2}$

In the on-going political transformation the Estonian president Päts and the Latvian president Ulmanis retained their presidential positions, and also some of their power, particularly if and when it was used in support of the occupying power. Indeed, when reading the Riigi Teataja ${ }^{3}$ it becomes clear that Päts used his presidential power more actively than ever before. For example, during one month, from June 21 to July 21, the Riigi Teataja published 126 presidential written orders or decrees, 34 new laws presented as presidential decrees, and 4 ordinances. All these laws, in one way or another, were aimed at the liquidation of the Estonian state and its independence, and relieving the state's administration and other leading employees from their posts. A decree signed on June 27, 1940 abolished the Home Guard, on the next day the Minister of War released all members of this organization from their oath - thus effectively destroying the last props of Estonian independence. ${ }^{4}$ Soon after, on July 5, Päts signed a decree for the establishment of People's Self-Defence (Rahva Omakaitse) a paramilitary organization made up of workers and communists, under the command of the Minister of the Interior. ${ }^{5}$

Meanwhile all three Baltic states were busy sorting out their now mixed-up foreign relations, obviously at the request of the occupying power - the Soviet Union. On June 28 the Estonian government, led by Prime Minister Vares, announced the denunciation of the Estonian-Latvian defense alliance. On June 25 Hans Rebane, the Estonian envoy to Latvia, had approached Kirhenšteins for the Latvian concurrence in the matter. On June 29, the Latvian Cabinet decided to ask President Ulmanis to sign the cancellation of documents concerning EstonianLatvian alliance. ${ }^{6}$ On June 30 the Estonian government announced the denunciation of the Estonian-Latvian-Lithuanian Treaty of Friendship and Cooperation (the

2 Ibid.

3 Estonian governmental publication that recorded all enacted laws for public consumption.

${ }^{4}$ See Riigi Teataja, June 27, 1940; Order by Minister of War. - Eesti Riigiarhiiv (ERA), 527-1-382, 60.

5 Riigi Teataja, July 8, 1940.

6 The Occupation and Annexation of Latvia 1939-1940. Documents and Materials. Riga, 1995, 240. 
Baltic League or Baltic Entente) signed on September 12, 1934. On July 3 Ulmanis signed a declaration which in content concurred with the Estonian announcement. ${ }^{7}$ Thus on the request of Soviets both the Estonian-Latvian Defense Alliance and the Baltic League were liquidated. The Baltic states did not object to Moscow's demands to hand over more and more territories for the Red Army. On July 5 Andrei Zhdanov, Politbureau member and Communist Party's First Secretary of the Leningrad District and City Committee signaled to Moscow that the Estonian government had agreed to lease out more land, particularly on the islands, for the use of the Red Army and Navy. ${ }^{8}$ Already on the next day the confidential agreement was signed by Zhdanov and Vladimir Botshkaryov for the Soviet Union and by Prime Minister Vares and Foreign Minister Nigol Andresen for Estonia, covering leases for various land-areas and other property. ${ }^{9}$

It must be pointed out hereby that the documents normally requiring Päts's and Ulmanis's signatures were now written by the newly appointed members of the Cabinet, of course approved by Moscow, who acted on the orders of the Soviets, or compiled outright by their administrative masters in Moscow. Thus former autocratic rulers of Estonia and Latvia had become the lowly signers of acts and documents compiled and prepared in Moscow.

After June 17 the members of the governments as well as the Ministries of Foreign Affairs of all three Baltic states continued making announcements, to their own people and to the world at large about their new governments having been formed according to constitutional laws. Furthermore, these statements stressed that the independence of all three Baltic republics would remain intact, but their orientation in terms of foreign policy will be focused on the Soviet Union only. On June 22 the Lithuanian Deputy Prime Minister and the Foreign Minister Vincas Krèvè-Mickevičius telegraphed to Lithuanian foreign representatives: "The foundation of the existing political system will not be changed. The inviolability of private property is guaranteed ... good relation with the Soviet Union is the priority of the new government." circular dispatched to the envoys in foreign countries expressed similar ideas. It emphasized that the new situation was the outcome of the previous six year long authoritarian political régime governance, and that the concluded Mutual Assistance Pact and the additional Red Army units arriving in the country should not be interpreted as invasion by a foreign power, but as means of supporting Estonia's security. Nevertheless, the former Estonian government led by Prime Minister Jüri Uluots and the former leadership of the Estonian armed forces were accused of harboring anti-Soviet feelings. The circular also demanded the rebuttal of all

7 The Occupation and Annexation of Latvia 1939-1940, 241.

Архив внешней политики Российской Федерации (AVPR), 06-2-28-359, 18-19.

9 Полпреды сообщают. Сборник документов об отношениях СССР с Латвией, Литвой и Эстонией август 1939 г.-август 1940 г. Москва, 1940, 455-457.

10 Полпреды сообщают, 420; see also Kreve-Mickevicius' telegram to the legation in Bern, June 26, 1940. Lietuvos okupacija ir aneksija 1939/1940. Dokumentu rinkinys. Vilnius, 1993, 304-305. 
allegations about the matter of occupation and the probable annexation of Estonia by the Soviet Union. In order to win the Soviet Union's real trust, Estonian diplomatic representatives were requested to cooperate with Soviet foreign representatives at their respective stations. ${ }^{11}$ This kind of disinformative statements were possible only because the previous Estonian, Latvian and Lithuanian governments had not rejected accusations put forward in respective ultimatums, and had later blessed all demands made by the Soviet Union with their silence.

New elections for Estonian and Lithuanian parliaments had been mentioned already in declarations covering the swearing in of the Vares and Paleckis governments. The same issue was handled vaguely in Kirhenšteins governmental statement, as referred to following the requirements of the 1922 Constitution, and restoring people's rights. ${ }^{12}$ In the beginning of July Moscow raised the question of organizing new parliamentary elections in all three Baltic countries. The purpose of these elections, planned by Moscow and respective June-governments, was to legitimize the situation in the Baltic states after the June 15 events. Consequently, on July 5 Päts and Ulmanis signed governmental decrees for organizing parliamentary elections on July $14-15$. On the same day a similar decision was taken by the Paleckis's Cabinet. ${ }^{13}$ Because of the Estonian and Latvian unseemingly speedy elections, these can be considered illegitimate. According to the Estonian Constitution these elections should not have been carried out until the middle of August, whereas the Latvian 1922 Constitution determined that the elections should have been held 40 days after the proclamation of coming elections. In case of Lithuania, its government by ignoring the requirements of the Constitution in its July 5 decree, lowered the voters' age-limit from 24 to 21, thus granting voting rights to conscripts of the armed forces. This action by the Lithuanian government also has to be considered illegal.

Even now Päts still expressed his wish for Germany to act against the Soviet actions. On July 3 Hans Frohwein, German envoy to Estonia, telegraphed Berlin, that "the President tries to preserve his position in the government as long as possible, preventing the re-organization of the government and the unification of his country with the Soviet Union. According to Frohwein the president expressed hope that Germany, because of its own economic interests, might consider preventing the bolshevization of Estonia". ${ }^{14}$

11 Circular of the Estonian Foreign Ministry to envoys posted abroad (undated). - ERA, 957-17-5, 214-216.

12 Полпреды сообщают, 402; Sotsialistlikud revolutsioonid Eestis 1917-1940. Eesti NSV astumine Nõukogude Liidu koosseisu. Dokumente ja materjale. Tallinn, 1986, 123; The Occupation and Annexation of Latvia, 239.

13 Regulation of the Cabinet of Ministers of Estonia, July 5, 1940; Decree of President, July 5, 1940; 1940. aasta Eestis, 11-114; Minutes of the Meeting of the Cabinet of Ministers of Latvia, July 4, 1940. The Occupation and Annexation of Latvia, 282-284; Minutes of the Meeting of the Cabinet of Ministers of Lithuania, July 5, 1940. Lietuvos okupacija ir aneksija 1939/1940, 328-329.

14 Frohwein's telegram, July 3, 1940. - DGFP, D, X, 107-108. 
Only Lithuanian Deputy Prime Minister and the Foreign Minister KrèvèMickevičius claimed later that while meeting Molotov in Moscow at the beginning of July, he had tried to resist the Soviet plan to bolshevize Lithuania. ${ }^{15}$

The Baltic election campaigns did not touch upon the possibility of a change in the political system, but stressed the orientation toward the Soviet Union in the future. Also foreseeable changes in social and cultural life according to the model of the Soviet Union were predicted, while assuring the continuation of the independent statehood for the countries. Speaking of the foreign policy issues, for example the Estonian Working People's Bloc in its election platform called for "Friendship between Estonians and the peoples of the Soviet Union, and for a close alliance between the Estonian Republic and the Soviet Union." 16

The Soviet Union attempted to hide its true objectives, and to leave an impression to the rest of the world that the Baltic states will retain their independence. In Estonia one of the steps taken in this direction was the showcase accreditation ceremony extended for the new Soviet envoy in July 1940. Vladimir Botshkaryov, presenting his credentials in Tallinn, stated that the Soviet Union intends to honor the independence of Estonia and that the Tartu Peace Treaty concluded on February 2, 1920 remains the basis for future relations between the two countries. Estonian president Päts, responding to Botshkaryov, announced that the Mutual Assistance Pact concluded on September 28, 1939 had fostered strengthening of mutual security, that the mighty Red Army had received a cordial reception by Estonian people, and that the peace policy of the Soviet Union will assure for Estonian people the use their creative powers and the invaluable possibilities in work for the future development. ${ }^{17}$

\section{ATTITUDES OF FOREIGN STATES}

Next the attitudes of the foreign states toward the occupation and the subsequent incorporation of the Baltic countries by the Soviet Union will be examined. In June 1940 altogether 19 states held diplomatic relations with the Baltic states, and were in an active manner mutually involved in each other's undertakings. But when the crisis hit the Baltic States, none of these foreign states attempted to actively support the prey of the aggressor nor officially protest against the Soviet ultimatums and events that followed. Obviously everybody involved considered remaining outside the conflict more advantageous than being drawn into it, although it was generally expected that the military actions of the Soviet Union in the region meant the end of independence of the Baltic states. Any self-instigated protests

15 Krèvè-Mickevičius, V. Bolševiku invazija irliaudes vyriausybe. Vilnius, 1992, 10-13; Вайшнорас Ю. Сентябрь 1940 года. Визит к Вышинскому. - Коммунист. Журнал центрального комитета коммунистической партии Литвы, 1989, 9, 89-90.

17 Botshkaryov' speech and Päts's speech July 17, 1940. - ERA, 957-7-534, 1-2. 
would surely aggravate the relations between the Soviet Union and the protesting states. Furthermore, it must be pointed out that at the same time the events in the Baltic countries were eclipsed on the international stage by the ongoing war in Western Europe.

Germany was a superpower whose policies substantially influenced the fate of the Baltic states. Hitherto Germany's unofficial foreign policy had only made oral promises to prevent the Soviet Union from liquidating the independent Baltic states through political and diplomatic efforts. As these states were occupied by the Soviets, Germany's official attitudes became more reserved, but at the same time more supportive of official German policies. The German media, controlled by Joseph Goebbels, Minister of Propaganda, disclosed only information agreeable to the German government. Therefore the German press published only brief communiqués received from $\mathrm{DNB}^{18}$ without any commentary related to the Soviet demands, and the occurring developments in the Baltic countries. The discreetness in publishing news about events in the Baltic States was justified with the claim that events taking place in the Baltic states were unimportant compared to those occurring it the West. ${ }^{19}$ Goebbels recorded a short appraisal of the situation in the Baltic States in his diary: "The clamor in the Balticum continues. It seems that Moscow wants to create a tabula rasa in these countries. This is the most sensible thing that can be done there." ${ }^{20}$ But it would be wrong to assume that the Soviet expansion was agreeable to all German diplomats, politicians and press. In private discussions many of them expressed overwhelming discontent. Thus the Lithuanian envoy in Berlin, Kazys Škirpa, analyzed at length in the report written to the Foreign Minister Krèvè-Mickevičius on June 22 Germany's and the Germans' attitudes concerning the Baltic states: "On the basis of private discussions and unofficial sources, it is reasonable to conclude that Germany follows the events in Eastern Europe and Lithuania very carefully. Harsh comments were uttered against the Soviet Union. This expresses the Germans' genuine opinion, but regrettably only unofficially. One can safely conclude that as long as Reich is engaged in Western Europe, there is no reason to expect any changes and new political trends in Eastern Europe, particularly in the regions important to Germany. Presently, everything gets registered only for future accounting of the actions taken. No doubt these accounts will be settled sooner or later. The question remains - when?"21

In the summer of 1940 Berlin did not plan to take any political steps for the support of the Baltic states. The official view of Germany in this matter was published on June 17. On this day Ernst von Weizsäcker, the State Secretary of the Auswärtiges Amt, declared to German diplomatic representatives that the activity

18 Deutsches Nachrichtenbüro.

19 See for example Berliner Börsen-Zeitung, June 17 and 20, 1940; see also Peltovuori, R. Sankarikansa ja kavaltajat. Suomi kolmannen valtakunnan lehtistössä 1940-1944. Helsinki, 2000, 65 .

20 Дневники Йозефа Геббельса 1940-1941 гг. - In: Новая и новейшая история, 61994, 222.

21 Lietuvos Okupacija ir Aneksija 1939/1940, 294-298; See also Škirpa, K. Sukilimas. Lietuvos suverenumui atstatyti. Dokumėntinė apžvalga. Vasingtonas, 1973, 19. 
of the Soviet Union in the Baltic States concerns only Russia and the Baltic states, and there is no reason for Germany to worry about it. ${ }^{22}$ Berlin was interested in preserving the status quo as it had been established with the concluded treaties with the Soviets on August 23, and September 28, 1939. Pavel Sudoplatov, a close aid of Lavrenti Beria, the Commissar of Internal Affairs, refers to Germany's unofficial position in his memoirs. According to Sudoplatov, during the second half of June, 1940, the Soviet Military Intelligence had received a signal that Germany had advised Estonia, Latvia and Lithuania to accept the Soviet ultimatum. At the same time Germany had indicated that the annexation of the Baltic states by the Soviet Union would be temporary. ${ }^{23}$ However, up to the present time no documentary proof in support of Sudoplatov's claim has been found. Taking into account Germany's desire to continue its impartial policy toward the Soviet Union, one must assume that this information had surfaced through unofficial channels.

On the other hand one should consider Germany's financial and economic interests in the Baltic States, and its concern for the Germans left behind in the Baltic countries.

In the report written on 18 June, Frohwein, the German envoy in Tallinn, states that the Soviet occupation and bolshevization will considerably restrict the German financial interests in Estonia, particularly those related to the oil-shale production and to the mining of phosphorite. ${ }^{24}$

In fact Estonian oil produced from the oil-shale, was of special importance to Germany. On October 7, 1939 a supplemental trade agreement between Estonia and Germany was signed in Berlin, which granted the delivery of 100,000 tons of shale oil to Germany in exchange for determined amounts of coal and coke. On May 41940 an additional contract between Estonian Ministry of Finance and German $\mathrm{OKM}^{25}$ promised another 10,000 tons of shale oil to Germany against the already ordered war materials. With these two contracts Estonia was providing Germany with oil needed to make war and to sink allied shipping worldwide.

The nationalization carried out by the Soviet Union in the Western Ukraine had substantially hurt Germany's financial interests. This precedent allowed the assumption that the Soviet government will carry out nationalization also in the Baltic countries. The memorandum written on July 11 by Weizsäcker declares that German economical interests in the Balticum are substantial: food products, oil-shale and phosphorite imports are crucial for German war economy, and one should save what can be saved. ${ }^{26}$ To protect German financial interests - about

22 Baaside lepingust anneksioonini. Dokumente ja materjale. Tallinn, 1991, 155-156.

23 Судоплатов П. Разные дни тайной войны и дипломатии 1941 год. Москва, 2001, 110.

24 US National Archive II (NA II), RG-242, T-120, R-279, 214628.

25 Oberkommando der Kriegsmarine.

26 Memorandum by Weizsäcker and Memorandum by Wiehl, July 11, 1940. - NA II, RG-242, T-120, R-375, 280267-280273; Documents on German Foreign Policy 1918-1945. - DGFP, D (1937-1945), X. The War Years. June 23-August 31, 1940. Washington, 1957, 189-190, 28; see also Möllerson's report, June 28, 1940. - ERA, 957-17-5, 1. 
$200,000,000 \mathrm{Rmk}$ in trade each year and 200,000,000 Rmk in investments in the region - the establishment of special financial institutions in Kaunas, Riga and Tallinn was being considered. On the same day telegrams were sent to the envoys in the Baltic capitals expressing concern about German economic interests in the Baltic states. ${ }^{27}$ In the middle of July, a few days after "the Baltic elections", Werner von Schulenburg, the German ambassador in Moscow, forwarded a memorandum to Molotov which communicated the official German view, stating that although Germany had no reason to become involved in Soviet-Baltic relations, it was specifically interested in retaining its trade relations with the Baltic countries, allowing Germany to purchase 180,000,000-200,000,000 Rmk worth of commodities, goods and wares like in normal circumstances prior to the political upheavals in the region. ${ }^{28}$

In August 1940 the oil deliveries from Estonia were stopped by the Soviets. Nevertheless the production of oil-shale and gasoline continued at full speed, and by September Estonia ran out of all possible storage facilities. On September 3 in a letter to Estländische Steinöl A/G ${ }^{29}$, OKM, as the majority shareholder, demanded the continuation of oil deliveries according to the contract in force. Soon after, Karl J. Schnurre, director of the East-European Trade Department of Auswärtiges Amt, arrived in Moscow for talks. Schnurre, in the name of the German government, requested of the Soviet Union not to harm the German economical interests in the Baltic States. Later, time and again Berlin repeated the same demands asking the Soviet government to take the economic and trade matters of the Baltic states into account. The Germans were especially concerned about the fortunes left behind by the Baltic Germans who had returned to their "fatherland" on Hitler's command. The German government estimated that the amount the Soviets owed to the German government on the Baltic Germans' account came to about 315,000,000 Rmk. $^{30}$

After "elections" in the Baltic states were called, the German government assumed that the Soviet Union intends to annex the Baltic states. ${ }^{31}$ In his July 19 speech at the Reichstag Hitler blessed the incorporation of the Baltic states by the Soviets. The dictator announced that a designation of mutual spheres of interest will be followed by the rearrangement of German-Soviet relations. He also assured that neither Germany nor the Soviet Union have taken steps which would take them outside their respective areas of interest. ${ }^{32}$

27 Ibid.

28 Memorandum by Schulenburg, July 17, 1940. Полпреды сообщают, 472.

29 In Estonian - Eesti Kiviõli (Estonian Oil-Shale Consortium).

30 See Memorandum by Molotov, October 17, 1940. Документы внешней политики СССР 1940 - 22 июня 1941. - ДВП, ХХІІІ, кн. первая. 1 январ-31 октября 1940 г. Москва, 1995, 681; Vyshinski's telegram, November 8, 1940 and Memorandum by Vysinski, November 20, 1940; Memorandum by Molotov, November 25, 1940. - ДВП, ХХІІІ, кн. вторая, 1. 1 ноября 1940 г. -1 марта 1941 г. Москва, 1998, 29-30, 113, 129.

31 See Memorandum by Funk, July 9, 1940. - NA II, RG-242, T-120, R-375, 230269.

32 See Rahva Hääl, July 20, 1940. 
On July 21 the newly elected "parliaments" of Latvia and Lithuania proclaimed the wish to become part of the Soviet Union. Next day the Estonian parliament followed suit. On the same day the Lithuanian envoy Škirpa, and on the next day the Latvian envoy Edgars Krievinš protested to the Auswärtiges Amt, and requested the German government to declare concluded Baltic elections illegal and refuse to recognize the new Baltic governments. ${ }^{33}$ These protests did not bring any results. Instead the Auswärtiges Amt returned the previously mentioned letters of protest to the envoys. This action was justified with the argument that the Reich cannot accept the notes as they were not presented on behalf of the respective governments. Immediately thereafter, the Auswärtiges Amt asked the Estonian envoy to refrain from sending notes in the future. ${ }^{34}$ Therefore in the summer of 1940 the Baltic envoys to Germany believed that Germany would settle the Baltic question under more suitable circumstances sometime in the future. In view of this outlook, the Baltic representatives declared their readiness to cooperate with Germany. The Estonian envoy Rudolf Möllerson had already at the beginning of July brought up the question of Estonia's future, as well as his own personal situation at the Auswärtiges Amt. He informed the German authorities that he will remain in Berlin and place himself unconditionally at the disposal of German government for a possible future use in the matters concerning Eastern Europe and Estonia. The Former Estonian Foreign Minister Karl Selter and the legation's counselor Albert Tattar assumed similar positions. ${ }^{35}$

Regardless of unofficial assurances by the Germans that the restoration of independence of the Baltic states did not belong to the sphere of their interest. In reality the Baltic states, like so many other regions of Europe, had become the playing fields of Germany, used in international games played at this particular time. Already on January 10, 1941, Germany in its border treaty with the Soviet Union recognised the incorporation of the Baltic states by the Soviet Union de facto, as a reward to the Soviets for agreeing to the German annexation of Memel region in Lithuania. ${ }^{36}$ In reality the German foreign policy was geared to eventually uniting the Baltic States with the future Great-German empire. From this point of view, the German government found it advantageous to consider Estonia, Latvia and Lithuania a part of the Soviet Union until its final political accounting, and therefore accepted the Soviet incorporation of the Baltic states with alacrity. At the same time Germany made it clear that it would not recognise any revival of independence movements in the former Baltic states as well as elsewhere in

33 DGFP, D, X, 265-267.

34 Memorandum by Woermann, July 24, 1940. - DGFP, D, X, 286; see also Škirpa, K. Lietuvos nepriklausomybès sutemos 1938-1940, 418.

35 Memorandum by Kleist, July 3, 1940. - NA II, RG-242, T-120, R-785, 379939; see also Memorandum by Woermann, August 12, 1940. - NA II, RG-242, T-120, R-119, 117894.

36 ДВП, ХХІІІ, кн. вторая, 1, 302-303. The agreement concluded on the same day also regulated the question of properties belonging to the Baltic Germans and to the German citizens. The Soviet Union agreed to pay a total of 200,000,000 RMk for all properties under consideration, while Germany consented to pay 50,000,000 RMk to the Soviet Union for all the Balt-owned properties located in the German territories. - ДВП, т. XXIII, кн. вторая, 1, 303. 
the occupied Europe, as demonstrated by its disavowal of the exile government of Lithuania, established on June 23, 1941 in Germany. In fact, the government of Germany was actively involved in developing various proposals and plans for transforming the Baltic States along the lines of its racial principles - it was planned to Germanise all racially suitable people while deporting the undesirable element to the occupied regions of the Soviet Union. ${ }^{37}$

The Italian Foreign Ministry followed German and Soviet lead in the Baltic question. On July 22 the Baltic envoys in Rome presented their protest notes to the Italian Foreign Ministry, where they were ignored. ${ }^{38}$ Anyhow, Italy lacked vital interests in the Baltic states and Finland, instead its interest was directed toward the Balkans and the Mediterranean countries. The Winter War in Finland caused a sharp anti-Soviet reaction in the Italian public opinion. This reaction was now supported further by the "peaceful" surrender of the Baltic countries during the previous summer, thus increasing the general discontent about Soviet expansionist policies in Italy. It must be also recognised that the feelings and reactions in the matter were generally confused, and torn between the opposing views: some individuals and circles in Italy feared that after the incorporation of the Baltic states, the Soviet Union might turn its attention toward the Balkan and Mediterranean region. On the other hand, particularly after entering the war, Italy needed raw materials for its war industry and hoped to secure these from the Soviet Union. Therefore Italy wished to "eliminate" all misunderstandings in Italian-Soviet relations. On June 16 when the Soviet Union presented its ultimatums to Estonia and Latvia, Mussolini agreed to begin political discussions with the Soviet government for the clarification of both countries' interests in the Balkan-Danube region. A few days later Augusto Rosso, the Italian ambassador to the Soviet Union, delivered Mussolini's message to Molotov, which expressed the wish to revive Soviet Italy friendship, non-aggression, and neutrality treaties, concluded in 1933. This note stressed the non-antagonistic character of both countries' mutual relations. ${ }^{39}$ In the second half of July, a lively discussion was going on between the two parties about the respective spheres of interest. Molotov informed the Italian representative that the Soviet Union considered Italy's pretensions to the Mediterranean region fully justified. ${ }^{40}$ Consequently Mussolini assumed a positive stand with respect to the Soviet incorporation of the Baltic countries: on July 24 he told the Soviet ambassador in Rome that with this incorporation the Soviet Union is only reclaiming what had belonged to it at earlier times, and that Italy considers the action entirely commendable. Mussolini

37 Jonušauskas, L. Likimo vedami. Lietuvos diplomatinès tarnybos egzilyje veikla 1940-1991. Vilnius, 2003, 105; Bubnys, A. Vokečių Okupota Lietuva (1941-1944). Vilnius, 1998, 12-22.

38 Leppik's note, July 22, 1940; Anfuso to Mussolini, July 27, 1940. Itaalia diplomaadid teatavad. Itaalia välispoliitilised dokumendid sündmustest Eestis 1939-1940. Tallinn, 2001, 124-126.

39 Memorandum by Molotov, June 20, 1940. - ДВП, ХХІІІ, кн. первая, 355-356.

40 About the relations between the Soviet Union and Italy see Смирнова Н. Д. Неизвестные страницы Советско-Итальянских отношений 1939-1941 гг. по новым документам. - Новая и новейшая история, 1996, 2, 32-41. 
also announced that he had informed the Baltic envoys about Italy's disinterest in the Baltic question. On August 6, when all three Baltic countries had already been made part of the Soviet Union, Italy's Foreign Minister Count Galeazzo Ciano wrote in his diary that Mussolini, keeping in mind a future attack on Yugoslavia, wishes to send him quickly to Moscow for signing some kind of a demonstrative agreement or treaty with the Soviet Union. ${ }^{41}$

On the other hand, the position of Vatican with respect to the incorporation of the Baltic states into the Soviet Union was circumspect. In principle the Holy See declined to recognise any political changes occurring during the war as well as the unconstitutionally established governments. Based on Vatican's policies, the Lithuanian legation in Vatican after 1940 events was allowed to continue its work throughout the war years under the protection of papal state. ${ }^{42}$

What happened to the Baltic countries did not surprise the Hungarian government. The incorporation and the subsequent bolshevization of these countries had been predicted by the Hungarian diplomats already in the autumn of 1939 . Following the Pact of Munich the Hungarian diplomatic representatives determined that the Baltic states would not be able to resist the invasion neither by the Soviet Union nor by Germany. It was nevertheless believed in Hungary that regardless of becoming the base of military forces, the governments of the Baltic states will be allowed to continue their activities. ${ }^{43}$ Ferenc Rainich, an influential member of the foreign policy commission of the Hungarian parliament, declared to the envoy of the Soviet Union on July 19, 1940, that the "recent events in the Baltic states, i.e. the latest Soviet diplomatic victories have been impressive". The deputy was particularly moved by the fact that the Soviet Union had achieved its goals by employing diplomatic means only. ${ }^{44}$ Of course, it is uncertain whether other members of the Hungarian parliament agreed with Rainich's views.

Budapest possessed the correct information about the 1940 June-July events in the Baltic states. A report written in July by József Kristóffy, Hungarian envoy in Moscow, stated that the parliamentary "elections" had been held in the Baltic countries according to the standard communist methods. ${ }^{45}$ The Hungarian authorities also believed that the occupation of the Baltic states had been caused first by the success of German military actions in the West, and second, by the fear of the Soviets that Germany might attempt to use the Baltic area as its bridgehead in the region. ${ }^{46}$

41 Gorelkin's report, July 24, 1940. - ДВП, XXIII, кн. первая, 453-454; Ciano's Diary 19391940. Ed. M. Muggeridge. London, 1948, 281.

42 Jonušauskas, L. Likimo vedami, 115.

43 See for example Walter's report, October 10, 1938. - Magyar Országos Levéltár (OL), K63-1937-3-2864. Sharonov's report, June 21, 1940. Трансильванский вопрос. Венгеро-румынский территориальный вопрос и СССР. 1940-1946 гг. Москва, 2000, 33. 
On July 25 Ludvigs Ēḳis, the Latvian envoy in Budapest and Bucharest, asked the Hungarian Foreign Ministry not to recognise the Saeima's decision to join the Soviet Union. In his note he stressed that the new Latvian parliament had been elected contrary to the constitutional laws and with the support, and threat, of the Red Army units. One day earlier Ēķis had send a similar telegram to the Regent, Miklós Horthy. However, when asked whether the Latvian government had ordered him to protest, Ekkis was compelled to admit that it was his duty both as a legal representative of Latvia as well as a Latvian citizen, to point out the illegal actions in his country committed by the Soviet Union. ${ }^{47}$

On his part, Mihai Manoilescu, the foreign minister of Roumania, in his discussions with the Soviet envoy considered the note of Ëkis rather naive and promised to influence Ėkis for him to deliver all archives and property of the Latvian legation to the representatives of the Soviet Union without further ado. ${ }^{48}$

The Estonian envoy in Budapest and Bucharest, Johan Markus was able to accomplish the same task on July $31 .^{49}$ One month earlier in his report to Tallinn he had expressed pleasure that the Vares government had gained the trust of the Soviet government. ${ }^{50}$ The cabinet of Pál Teleki, placed into difficult position by the German-Soviet friendship, because of the occupation of North Bukovina by the Soviets, by German victories in the West, and by Hungary's economic dependence on Germany, accepted notes of Latvian and Estonian envoys but did not react to them. Hungarian ethnic kinship with Estonians did not seem to influence Hungary's attitude toward Estonia in any way. Hungary, because of its intention to occupy Transylvania, did not want to irritate Germany nor the Soviet Union with responding to the situation in the Baltic countries where Hungary lacked any serious interest. ${ }^{51}$ In fact, Budapest needed Moscow's support concerning Transylvania, and also desired to conclude a trade agreement with the Soviet Union. Eventually the Soviet government promised to back Hungary's demands against Roumania. On September 3, Hungary and the Soviet Union signed a trade agreement. Still, regardless of machinations for its own benefit, Hungary showed charity toward Estonia and Latvia by giving refuge to both countries' military attaches, Colonels Ludvig Jakobsen and Aleksandrs Plensners. ${ }^{52}$

Japan lacked any particular political interest in the Baltic states, although the Baltic states acted as an intermediary for collecting information about both Germany and the Soviet Union, and that a considerable amount of trade was transited through Estonian and Latvian ports. However, in the summer 1940 Japanese governmental circles, exhausted by the war in China, started to search for an agreement with the Soviet Union, which was supporting China in its war efforts.

\footnotetext{
47 Barthok's report, July 25, 1940. - OL, K63-1940-3-4330.

48 Memorandum by Lavrentyev, August 15, 1940. - ДВП, ХХІІІ, кн. первая, 515.

49 Memorandum by Markus, July 31, 1940. - OL, K63-1940-3/28, 4328.

50 Markus's report, July 29, 1940. - ERA, 957-17-5, 23.

51 Molotov's telegram to Sharanov, July 5, 1940. - ДВП, XXIII, кн. первая, 415-416.

52 Magyar Hadtörténelmi Levéltár (HL), Budapest HL HM Eln, 1940, 44736, 52438.
} 
The Japanese government, hoping that the Soviets would stop aiding China, proposed the conclusion of a suitable neutrality and non-aggression pact. This step was also important to Japan because of its wish to assure for itself a free hand in dealing with the United States in the Pacific region, and in conquering Asian colonies belonging to France and Netherlands. ${ }^{53}$ At the beginning of September the deputy Foreign Minister of Japan, Kuiki Ohasi, informed the Soviet ambassador about Konoe Fumimaro's government's approval of the Soviet incorporation of the Baltic states. Consequently the Japanese government assisted the Soviet embassy in Tokyo in taking possession of the archives belonging to the Estonian and Latvian honorary consulates. But at the same time Japan was interested in retaining its representation in Riga. This office had been very useful for collecting political, military, economical and intelligence information concerning the Soviet Union and the Eastern Europe in general. Referring to the trade transit passing through Latvia's ports, Tokyo proposed the establishment of a consulate general in Riga, but Moscow refused to accept the proposal. ${ }^{54}$

In June 1940, rumors circulated in Riga and Tallinn that behind the occupation of the Baltic states was the hand of Great Britain in the form of the new British ambassador to the Soviet Union - Sir Stafford Cripps. Thus President Päts in his talks with German envoy Frohwein accused Great Britain of inciting the Soviet Union to occupy the Baltic countries. According to Päts, Great Britain hoped that the occupation of the Baltic states would force Germany to transfer the bulk of its military might to the east, thus causing the soonest possible outbreak of the GermanSoviet war. ${ }^{55}$ The Estonian envoy in London, August Torma, writing about Cripps' mission to Moscow, considered Moscow's willingness to receive Cripps a cunning manoeuvre for exerting pressure on Germany. ${ }^{56}$

But was there any truth in the accusation of Great Britain for trying to create a rupture between Germany and the Soviet Union? On May 18, at the meeting of the British War Cabinet, relations with the Soviet Union were discussed and Lord Halifax, the Foreign Secretary, claimed that the Soviet Union should be concerned about the military successes of Germany, and for this reason it might be possible to come to some kind of an agreement. On Halifax's suggestion, also supported by Winston Churchill, it was decided to dispatch Cripps to Moscow. Indeed, Cripps, carrying truly friendly feelings toward the Soviet Union, was the right person for the planned mission to Moscow. It was up to him to find out what kind of trade and other agreements could be made with the Soviets. At the same time Cripps was not authorized to hold discussions and make decisions as a representative of the British government. In a memorandum written a few days later

53 See Сафронов В. П. СССР, США и Японская агрессия на Дальнем Востоке и Тихом океане. 1931-1945 гг. Москва, 2001, 220-222.

54 Smetanin's report, September 10, 1940. - ДВП, ХХІІІ, кн. первая, 507-508.

55 Frohwein's telegram, June 20, 1940. - NA II, RG-242, T-120, R-279, 214631; see also Palin's report, June 30, 1940. - Suomen Ulkoasiainministeriön Arkisto (UM), 5C/16.

56 Torma's report, June 6, 1940. - ERA, 957-17-5, 87. 
Halifax concluded that he did not harbor any illusions about the success of Cripps' mission, but "in the current situation all means have to be used for creating a rupture between the Soviet Union and Germany."

Moscow was ready to talk with Stafford Cripps only if he came as an accredited ambassador. London relented and named him the ambassador to the Soviet Union. Cripps arrived in Moscow on June 12 and had his first audience with Molotov on June 14, the day when Lithuania received its ultimatum. Cripps announced that Great Britain is willing to discuss the creation of a Balkan League under the protection of the Soviet Union. ${ }^{58}$ This proposal allows to deduct that indeed London tried to provoke a clash between the Soviets and the Germans. Documents in the archives do not show that the Baltic question was touched upon in these first discussions between Cripps and Molotov. In any case, at the time of the MolotovCripps meeting the Soviet invasion of the Baltic States had already begun. But on the basis of archive materials, it cannot be concluded that up to this time the British government through the person of Cripps had encouraged the Soviet Union to occupy the Baltic states. Furthermore, it would be wrong to assume that Moscow could have been influenced by the desires and wishes of Great Britain. However, it is clear that Stafford Cripps was one of the few British politicians, who already in the summer of 1939 wholeheartedly strove towards the formation of Tripartite Alliance against Germany, and in the fall of the same year had sanctioned the occupation of East Poland by the Red Army and the establishment of Soviet military bases in the Balticum.

In June 1940 Great Britain lost its ally - France - and therefore was vitally interested in a possible clash between Germany and the Soviet Union. ${ }^{59}$ At a War Cabinet meeting held on June 5, Lord Halifax announced that he had requested the United States government to take steps in Moscow for breaking up the alliance between Berlin and Moscow. ${ }^{60}$ At the same time Halifax's attitude concerning the occupation of the Baltic States was indifferent. According to Sir Henry Channon Halifax received the news of Lithuanian occupation with the words "this leaves me rather cold". ${ }^{61}$ On the June 17 meeting held by the War Cabinet, when the Baltic states were already occupied, it was suggested that the main motive for the Soviet expansion into the Baltic States was the desire to strengthen its defences against Germany, whose recent military successes had caused worry in Moscow. ${ }^{62}$ On July 18 Cripps' telegram from Moscow was discussed at the War Cabinet session. The ambassador's message explained that it had become clearer by the hour, that the Soviet government did not renounce its support to Germany's

57 Op cit. Сиполс В. Я. Миссия Криппса в 1940 г. Беседа со Сталиным. - Новая и новейшая история, 1992, 5, 25.

58 Ibid., see also Gorodetsky, G. Stafford Cripps' Mission to Moscow 1940-1942. Cambridge, 1984, 46.

59 See for example Gripenberg's report, September 2, 1940. - UM, 5C/7.

60 Public Record Office, Foreign Office (PRO), CAB 65/7, WM 167 (40).

61 The Diaries of Sir Henry Channon. Ed. R. R. James. London, 1967, 258.

${ }^{62}$ PRO, CAB 65/7, WM 170 (40). 
hegemony in Europe. This message is recorded in the protocol of the meeting: "In any case, Cripps does not detect any prospects in uniting with the Soviet Union into a common front against Germany." ${ }^{\text {"63 }}$ Any hope that the Soviets might change their mind about Germany was still not altogether abandoned, and Great Britain tried to comply with Soviet wishes as much as possible. This idea is supported by a remark recorded in the protocol of June 22 War Cabinet meeting: "The Foreign Secretary stated that as far as he can determine, the concentration of the Soviet armed forces in the Baltic states' territories can be interpreted as a strategic defensive measure taken by the Soviet Union." ${ }^{64}$

On June 24 Halifax sent instructions to Cripps advising him how to conduct discussions with Stalin. These instructions also reflect the attitude of the British government to the Baltic question. Halifax wrote: "When the question about the Baltic states arises, then you can indicate that you accept his explanation for recent Soviet actions in the Balticum - i.e. since these were induced by Germany's threatening military successes that put the Soviet Union in danger, and therefore justified it to undertake defensive moves for self-protection, which in different circumstances would have drawn negative criticism." ${ }^{65}$ However, the protocol of July 1 meeting between Stalin and Cripps did not mention the Baltic states at all, although some indirect hints concerning the occupation of these states could be detected. Cripps underlined Great Britain's wish for balancing the contending forces in Europe as well as in the Far East, and that in this light Great Britain understands the actual policies of the Soviet Union in the ongoing war. ${ }^{66}$ At the same time Churchill informed Ivan Maisky, the Soviet ambassador in London, that even if Soviet Union's expansion in Bessarabia means its return to the imperialist policies of the Russian czars, he, Churchill, cannot come up with any rational counter-arguments criticizing the new policies of the Soviet Union. ${ }^{67}$ Regrettably, some protocols of the War Cabinet meetings during these fateful days for the Baltic countries are still unattainable for the researchers and historians to this day.

All three Baltic states disappeared from the map of Europe quietly. However, the British press expressed compassionate views about the Baltic people's loss of independence. The London Times published an editorial which stated that whatever happened, the period of the Baltic independence had not proven altogether futile: the Baltic languages and literature had achieved world recognition. The acceptance of the annexation by the left-wingers and some higher army officers was explained, besides yielding to the Soviet pressure, with the patriotic wish to save these countries from German occupation. ${ }^{68}$ The British legation in Riga found in its reports that the disappearance of the Baltic states was determined largely as

63 PRO, CAB 65/7, WM 171 (40).

${ }_{64}$ PRO, CAB 65/7, WM 175 (40).

65 Ор cit. Сиполс В. Я. Миссия Криппса в 1940 г., 30; see also Baaside lepingust anneksioonini, 192.

66 Conversation between Stalin and Cripps, July 1, 1940. - ДВП, ХХІІІ, кн. первая, 394-399.

67 Maiski's telegram, July 3 and 4, 1940. - ДВП, ХХІІІ, кн. первая, 409.

68 The Times, July 25, 1940. 
the consequence of the authoritarian régimes previously in power in all three states. For example, the report of July 26 written by the legation's secretary Douglas MacKillop analyzed the new situation in Latvia and found that its many workers would have voted for the candidates of Working People's Bloc even if suitable alternatives would have existed. In MacKillop's view the political and economic conceptions of President Ulmanis resembled the ideals of the 19th century middle-class nationalism, and regardless of his service to his country, Ulmanis was not the person who could have organized his people for an effective resistance against the feared invader. According to MacKillop the Latvian state of 1940 with its 20-year history was able to display only idle hostilities, weakened by notable corruption and deep-rooted suspicions: Latvia with its foreign trade controlled by the Jews and by the Baltic Germans, was a state excessively overadministered where civilian as well as military expenses were grotesquely disproportionate to the available resources and Latvian nationalism, regardless of its romantic and bellicose aspirations, was in the end nothing more than a worthless hubbub. If MacKillop's opinion of the Ulmanis régime in Latvia were accepted, then his final conclusion has to be considered as a typical view of the representative of a Great Power in regard to small nations and their states: "Considering them [Latvians] as a tribe rather than as a nation, the Letts have given proof over centuries of their history of real individuality and power successfully to resist assimilation, and there is no reason to suppose that their distinctive culture and characteristics will be lost in their newest adventure." $" 69$

On July 23 the Baltic envoys in London delivered notes of protest to the Foreign Office against decisions made under the pressure of the Red Army's presence in the newly elected parliaments. The British government kept these notes under consideration for more than a month, when it was decided not to answer by a written note. The Baltic envoys were informed orally that they were allowed to continue working under the previously established rules. ${ }^{70}$ On June 20 the British authorities had frozen and blocked all Baltic accounts and treasures held in Great Britain for safekeeping. The British government viewed Baltic gold as the surety for British investments and properties in the Baltic countries. The total of British holdings in the Baltic countries was appraised to be worth $£ 3,848,000$. The value of Baltic gold held by Great Britain was estimated to be $£ 3,866,000$. Whereas the value of the private property and investments held by the British subjects in the Baltic states was estimated to be $£ 3,768,000$, of which 1,460,000 was in Estonia, 1,708,000 in Latvia and 600,000 in Lithuania. ${ }^{71}$

In the summer of 1940 the Baltic states were viewed by Great Britain as barter goods. The British government saw in the Soviet Union a prospective ally, and

${ }^{69}$ MacKillop's report, July 26, 1940. - PRO, FO 371/24761, N 6045/1224/59.

70 Torma to Rei, January 28, 1941. Baltiska arkivet (BA), Rei 8.

71 Anderson, E. British policy toward the Baltic States, 1940-1941, 329, 332; Zunda, A. Baltijas valstu problēma un Lielbritānija. Otrā pasaules kara gados (1939-1945). - Latvijas Vēsture, 2004, $3(55), 67$. 
regarded improving its relations with the Soviet Union important to such a degree, that it even considered recognizing the incorporation of the Baltic states de jure. On July 26 the recognition of Baltic puppet governments was discussed in the War Cabinet - obviously the good relations with the Soviet Union were more important to Great Britain than the fate of the Baltic countries. A memorandum of the same date, signed by Lord Halifax, remembering the fate of Austria and Czechoslovakia, that considering the moral aspect of the question, nothing positive can be said in support of refusing the recognition. But taking British interests into account, Halifax had to admit that the recognition of the completed annexation will not be advantageous to Great Britain in the long run. ${ }^{72}$ At the July 29 meeting, the War Cabinet agreed with Halifax's position. But at this sitting also views opposed to the recognition were aired: the recognition of incorporation will deliver to the German propaganda machine an opportunity to appear as a defender of small nations, and will cause pronounced discontent in the Polish, Norwegian, Dutch and Belgian governments, also in Finland and in the Scandinavian countries. Against the recognition spoke also an assumption that in case of the recognition Great Britain would have to hand over to the Soviet Union the Baltic gold and all Baltic ships docked in the British ports, instead of keeping all that as compensation for British properties and investments left in the Baltic states, now nationalized by the Soviets. The most powerful argument against the recognition arose from Great Britain's relationship with the United States. The British government understood that the recognition of the Baltic states incorporation will cause a negative reaction in the United States public opinion, and will create an undesirable precedent, which would pressure Great Britain to also recognise the German and Japanese conquests. Also it appeared improbable that under the present circumstances recognition of the Baltic states incorporation would change the attitude of the Soviet Union toward Great Britain. ${ }^{73}$ On August 8 the British War Cabinet decided to postpone the question of the Baltic states' incorporation by the Soviet Union. Consequently, in conflict with Washington which kept on talking about the occupation of the Baltic states, London declined from taking an official stand in the matter. Nevertheless, certain quarters retained their desire to improve relations with Moscow, and meet its requirements. A few days after the incorporation of the Baltic countries into the Soviet Union, Georg Gripenberg, the Finnish envoy in London telegraphed Helsinki stating that the Secretary of State in the Foreign Office, Richard A. Butler had remarked that if the agreement about the compensation for British investments and properties in the Baltic States would be concluded, London will promptly recognise the uniting of the Baltic states with the Soviet Union. ${ }^{74}$

72 Memorandum by Halifax, July 26, 1940. - PRO, FO 371/24761/3913, N 6081/1244/59.

73 PRO, CAB 66/10 WP 280 (40) and CAB 65/8, WP 214 (40); Cripps's report, August 24, 1940.PRO, FO 371/24765; Cripps's report, August 4, 1940. - PRO, FO 371/24761; see also The Diaries of Sir Alexander Cadogan O.M. 1938-1945. Ed. D. Links. London, 1971, 320.

74 Gripenberg's telegram, August 10, 1940. - Suomen Kansallisarkisto (KA), Tanner 39; see also Gripenberg's report, September 2, and November 19, 1940. - UM, 5C/7. 
Even Lloyd George, the former liberal Prime Minister, criticized the indefinite and fuzzy policies of the British government regarding the Baltic question. In commenting on the incorporation of the Baltic states, he described the behavior of the government as sucking up to the United States of America and recommended that in the prevailing situation the British government should primarily orient itself toward the Soviet Union. ${ }^{75}$

In spite of Churchill's declaration in the Lower House on September 5 that the British government does not recognise any territorial changes occurred during the war that have not taken place by mutual agreements through free will, the incorporation of the Baltic states continued to stay on the government's agenda. ${ }^{76}$ In September 1940 Lord Halifax informed the Soviet ambassador Maiski that the Baltic question could be resolved only if the Soviet Union would give up its claim to the Baltic gold stored in British banks. ${ }^{77}$ This proposal basically meant selling out moral principles for money.

During the rest of the 1940s the battle within the British government about the Baltic question continued. Soon the government through the Foreign Office announced that no visas will be granted to Latvian refugee-politicians nor will the establishing of Latvian National Committee be permitted in Great Britain - to avoid straining the relations with the Soviet Union. ${ }^{78}$ At the same time Great Britain was interested in concluding a trade agreement with the Soviet Union. On September 14 ambassador Cripps proposed unofficially to the Soviet government to freeze all mutual claims and counter-claims until the end of war, or at least until Great Britain succeeded in fending off the German aggression. ${ }^{79}$ He advised Moscow to realize that the British government cannot retreat in the Baltic question, because a precedent would be created by this action which will bring along other problems related for example to Czechoslovakia and other occupied countries. In fact, at this time the kings and queens of the Netherlands, Greece, Norway and Yugoslavia, the Belgian government, the presidents of Czechoslovakia and Poland in addition to the National Committee of France had found asylum in Great Britain. Cripps also indicated that retreating in the Baltic question would likely cause an undesirable reaction in the United States. He also proposed that the Soviet claims on the Baltic gold should be handled through the British civil court. ${ }^{80}$

On September 27, 1940 Germany, Italy and Japan established the so-called Triple Pact in Berlin which finalized the collaboration of Axis-powers. This development brought along certain changes in the thinking and attitudes of Great Britain. The British government surmised that from this time on the German expansion will be directed to Southern Europe and the Italian expansion to Northern Africa, while hoping that the Japanese expansion can be re-directed from South-

75 Maiski's telegram, August 14, 1940. - ДВП, ХХІІІ, кн. первая, 511.

76 PRO, FO 371/24761, N 6581/122/59.

77 The Diaries of Sir Alexander Cadogan, 320.

78 Anderson, E. British policy toward the Baltic States, 1940-1941, 329.

79 Memorandum by Vyshinski, September 14, 1940. - ДВП, ХХІІІ, кн. первая, 599.

80 Ibid., 599-600. 
eastern Asia back to China's mainland. Consequently the Soviet government was informed that Great Britain is willing to give necessary credits to China for purchasing required armaments from the Soviet Union. ${ }^{81}$

On September 17 Cripps proposed to the Soviet government to conclude an agreement in the matter of "temporarily requisitioned Baltic merchant ships", 82 indicating that the British government would go to extremes to reach the agreement. ${ }^{83}$ On the same day Lord Halifax in his talks with the Soviet ambassador stressed time and again that the British government wishes ardently to improve its relations with the Soviet Union. But when ambassador Maiski noted that the actual politics of the British government in the matter of Baltic ships did not seem to support the wishes of the Foreign Secretary, the latter stated that the Baltic ships' question was a "small one" and should not eclipse "the big questions" which require close cooperation between the two countries. ${ }^{84}$ Already on the next day London signaled to Moscow, that Great Britain is ready to discuss the matter of Baltic ships and the necessary re-imbursements to the Soviet Union. ${ }^{85}$ On October 22 Cripps delivered a British memorandum to the Soviet government, which contained a proposal to normalize mutual relations by concluding an agreement between the two countries, and a request that the Soviet government from this time on would pursue benevolent neutrality toward Great Britain. Great Britain in its turn promised to avoid joining any anti-Soviet alliances and to recognise Soviet sovereignty over the Baltic states, Bessarabia, Northern Bukovina and Eastern Poland de facto. ${ }^{86}$

Anthony Eden, becoming the Foreign Secretary in December 1940, brought along a change in relationships with the Baltic envoys. Hitherto the Foreign Office had been willing to listen to whatever the envoys had to say, but at the end of December accepting the envoys" "private letters" was stopped. From then on they were permitted to keep in touch with the Northern Department of Foreign Office only. ${ }^{87}$

From the beginning of 1941 the German pressure on Yugoslavia and Turkey started to increase. Consequently the weight and influence of the British politicians who considered the normalisation of relations with the Soviet Union vital, grew

81 See Maiski's telegram, October 1, 1940 and Memorandum by Maiski, October 3, 1940.ДВП, ХХІІІ, кн. первая, 647-648.

82 British authorities requisitioned the Baltic merchant ships (20 under Estonian, 3 under Latvian and 1 under Lithuanian flags) docked in the British ports. This action, taken on October 14, 1940 was justified with the claim that the British government needed these ships. This reasoning can be accepted, because in the prevailing war considerable losses in British merchant fleet had been caused by German submarines and airplanes. The original national crews were allowed to continue manning their respective ships. Memorandum by Vyshinski, October 17, 1940. - ДВП, ХХІІІ, кн. первая, 674. Vyshinski's telegram, October 18, 1940. - ДВП, XXIII, кн. первая, 690. ДВП, XXIII, кн. первая, 701-705.

Anderson, E. British policy toward the Baltic States, 1940-1941, 331; Zunda, A. Baltijas valstu problēma un Lielbritānija, 68. 
steadily from day to day. Some members of the government became increasingly willing to make far-reaching concessions, including in the Balkans. Cripps in Moscow even proposed to the Soviets that Foreign Secretary Eden could meet with Stalin - a suggestion which was turned down by the Soviet government with a comment, that "it was not a right time for solving the "big questions". ${ }^{88}$ On April 3 Churchill dispatched the next successive letter to Stalin in which he again drew attention to the many possible courses for German expansion. The attitude of Churchill toward the British-Soviet relations and toward the Baltic question in the spring of 1941 is clarified by his instructions to the Foreign Office delivered on April 22. The central issue of this communication was the question whether or not Moscow should be told that the British government would recognise its incorporation of the Baltic states, if the Soviet government would start moving closer to the British position. ${ }^{89}$

But the outbreak of the Soviet-German war on June 22, 1941 made Great Britain immediately an ally of the Soviet Union. On July 12 the agreement for BritishSoviet cooperation in fight against Hitler's Germany was signed in Moscow. In time this agreement became the basis of the developing coalition against Germany and its allies. During the visit of Eden to Moscow in December 1941 the Baltic question was one of the issues discussed by the new allies. During his repeat visit on September 17, 1942 Stalin made two proposals: first, to conclude a collaborative military agreement for the duration of the war, and second, to conclude also an agreement for cooperation after the war. At the same time the Soviet government announced that a mutual assistance pact would be possible only if Great Britain recognised the western borders of the Soviet Union, dated June 22, $1941 .{ }^{90}$ This meant, of course, de jure recognition of the incorporation of the Baltic states and Bessarabia into the Soviet Union. But taking into account the requirements of the Atlantic Charter, Eden would not agree with the Soviet proposals, causing the discontinuation of further negotiations. It seems that Great Britain was interested in Soviet alliance for the on-going war, while the Soviet Union was already considering the shape of the world after the war.

The analysis of Soviet-British relations made in the Foreign Office concluded that, first, Great Britain should not take on any onerous duties concerning Eastern Europe, second, that Great Britain in its policies must take into account the strategic interests of the Soviet Union, and third, that it should employ the principles of Atlantic Charter in a different way in various locations, depending on the location and population in question. At the same time the British government kept on worrying about the American reaction to its yielding policies toward the Soviet Union, particularly concerning the Baltic question. ${ }^{91}$

88 Memorandum by Vyshinski, February 24, 1941. - ДВП, ХХІІІ, кн. вторая, 1, 416-417.

89 Rothwell, V. Britain and the Cold War. London, 1982, 77-78.

90 Seе Ржешевский О. А. Война и дипломатия. Документы и комментарии (1941-1942). Москва, 1997, 11-61; The Eden Memoirs: The Reckoning. London, 1965, 303.

91 Zunda, A. Baltijas valstu problēma un Lielbritānija, 69. 
In May 1942 the Soviet Peoples' Commissar of Foreign Affairs, Molotov, visited London. At the beginning of talks about concluding the mutual assistance pact, the British government agreed to recognise the western borders of the Soviet Union, dated June 22, 1941. ${ }^{92}$ But during the following talks the British position regarding the status of the Baltic States changed, and the Soviet Union was forced to accept the British stand in this issue. The British position had shifted because of first, the military situation on the western front having turned catastrophic for the Soviets, and second, because the recognition of Soviet western borders was also of deep concern to the exile government of Poland as well as to the government of the United States, as demonstrated in the June 13, 1942 memorandum of the American Secretary of State Cordel Hull. ${ }^{93}$ Therefore the Soviet-British alliance and mutual assistance agreement signed on May 26, 1942 directed against Germany and the Axis power, only expressed the desire of both partners to cooperate in preserving peace in the post-war world, and preventing the re-ascension of a military German state.

In the meantime the situation among the exiled Baltic diplomats stationed in London went through another transformation. Namely, on demand of the Soviet government, the Foreign Office removed the names of certain diplomats from its regular list and placed them in a special addendum with a title "The List of Persons Who Do Not Belong to the List of Accredited Diplomats But Are Considered by the British Government as Persons of Certain Diplomatic Status", without indicating from which country these persons were from. Thus all diplomats from Germanoccupied states remained on this list. The foreign Office advised the Baltic diplomatic representatives to avoid asking for an explanation in the matter. ${ }^{94}$

In the following period until the end of war, the British politicians and diplomats continued to express different views and proposed various plans. Repeatedly it was announced that the fate of the Baltic states will be determined at the peace conference after the war. Although during the years of war, the acceptance of Soviet demands seemed to take hold in the official policies of the British government, as well as in the press of the country. Nevertheless, the British government started to recognise the western borders of the Soviet Union dated June 22, 1941 diplomatically, but it simultaneously refused to recognise the incorporation of the Baltic states into the Soviet Union.

In the spring-summer of 1940 Paris was also dreaming about the Soviet Union entering the war. The French government sent a new ambassador, Erik Labonne, to Moscow, whose assignment was to make the Soviet government understand the necessity of joining the Western Allies. Already prior to the Soviet ultimatums to the Baltic states the instructions from the Quai d'Orsay to Labonne emphasized that discussions with the Soviet diplomats will be possible only if both France

92 Ржешевский О. А. Война и дипломатия, 76-77, 83.

93 The Papers of Cordel Hull. Library of Congress (LC).

94 See Jonušauskas, L. Likimo vedami, 106; Zunda, A. Baltijas valstu problēma un Lielbritānija, 70. 
and Great Britain do not question territorial changes in Eastern Europe: in Western Ukraine, Western Belorussia and in the Baltic states. ${ }^{95}$ Just before the surrender of France, Labonne, on the instruction of the Quai d'Orsay, attempted to get help from the Soviet Union. He warned Molotov that the defeat of allies in the West will imperil the balance of power and soon turn Germany to the East. At the same time Labonne alluded to "legitimate interests" of the Soviet Union. ${ }^{96}$ After the capitulation of France the so-called Vichy government was to take first and foremost the interests of Germany and Italy into consideration, thus assuring for itself a place in the New Europe. At the time the Soviet Union was viewed as a balancing element against Germany. Therefore Labonne repeatedly telegraphed Vichy with a warning that if France definitely does not want to lose its independence, it has to be extremely careful with respect to the Soviet Union. Labonne called upon the Vichy government to free itself of any sentimentality in its policies toward Moscow. According to Labonne, the Soviet Union will support France only if it is to its own best interest. Labonne treated the expansion of the Soviet Union in the Baltic States only as an activity directed against Germany. ${ }^{97}$

Like other diplomats, also those from the Baltic states soon left Paris for Vichy. The Vichy government did not express an opinion about the legal aspects concerning the incorporation of the Baltic countries by the Soviet Union, nor assumed any obligation in regard to the future of the Baltic states. On August 17, the Vichy government decided to take notice of the August 11 declaration of the Soviet government, which announced the unification of the Baltic states with the Soviet Union, and requested the closing of French embassies in all Baltic countries. The Vichy government stressed that assuming an official stand in the Baltic question at this time may not only be useless, but even dangerous from the standpoint of French-Soviet relations. ${ }^{98}$

In the autumn of 1940 Labonne and the Vichy government followed closely the activity of Stafford Cripps in Moscow. On October 22, Labonne reported to the Vichy government that Cripps had promised the Soviet Union that depending on its retaining its neutrality, London will recognise the incorporation of the Baltic states, and will not join any anti-Soviet alignments. ${ }^{99}$ The Vichy France press declined publishing materials, which would describe the events in the Baltic countries in the true light. Because the Soviet government was able to take advantage of the opponents of previous régimes in the Baltic states, there were many individuals in France who believed that joining the Soviet Union had been supported voluntarily by the majority of local people. Also the French people with anti-German feelings were glad that the occupation of the Baltic states by the

\footnotetext{
95 Челышев И. А. СССР - Франция: трудные годы 1938-1941. Москва, 1999, 301-302.

97 Суту Ж. А. Виши, СССР и Германия. 1940-1941 гг. По французским архивам. - Новая и новейшая история, 2000, 3, 122-125.

98 Ibid., 128.

99 Ibid., 126.
} 
Soviets eliminated the opportunity for the Germans to use the region to attack the Soviet Union. ${ }^{100}$

Kaarel Robert Pusta, an official with special assignments in the Estonian legation in Paris, removed from the office by the new Foreign Minister Nigol Andresen on June 29, later declared that he had presented a note to Paul Baudouin, the Foreign Minister of the Vichy government on June 29, in which he had protested the newly elected parliament's wish to join the Soviet Union. ${ }^{101}$ However, Oskar Öpik, the former Estonian envoy to France, later claimed in his memoirs that it was really he, who together with the Latvian and Lithuanian envoys, had delivered a joint protest to the Vichy government. ${ }^{102}$ All the same, Öpik's assertion seems ambiguous because at the same time he called the protest delivered to the Foreign Office by Estonian envoy August Torma completely valueless. ${ }^{103}$ In this case, was not his own effort along the same lines with the Vichy government similarly pointless? It is possible that in truth no note of protest was handed to the Vichy government. This assumption seems to be confirmed by the memoirs of the Lithuanian envoy in Paris, Petras Klimas. According to his reminiscences the Baltic envoys in France acted in unison after the conclusion of non-aggression treaties in 1939. This meant that all three representatives together presented a number of notes, first trying to convince the French government that the Soviet Union is a peaceful and benevolent country, and that Soviet garrisons did not violate the neutrality of the Baltic states - as instructed by their respective governments. ${ }^{104}$

But after the incorporation of the Baltic states, the tone of the diplomatic notes offered by the Baltic diplomatic representatives changed radically - now they asked the Vichy government to condemn the Soviet actions, i.e. the incorporation of the Baltic region. It has to be noted that the actions of Baltic diplomats were independent as they lacked the official backing of their governments.

At the end of 1940 the negotiations between the Vichy government and the Soviet Union regarding the Baltic gold deposited in French banks commenced. In March 1941 the French authorities agreed to hand over the gold to the Soviet Union, but because of the outbreak of the Soviet-German war these plans did not realize. ${ }^{105}$

The Spanish government did not make any official announcements regarding the incorporation of the Baltic states by the Soviet Union, but continued recognizing the accredited Baltic diplomatic representatives. The Portuguese government, on the contrary, decided not to recognise the incorporation of the Baltic states by the Soviet Union. ${ }^{106}$

100 See Holma's report from Vichy, September 2, 1940. - UM, 5C/6.

101 Medijainen, E. Saadiku saatus, 155; Pusta, K. R. Saadiku päevik. Tallinn, 1992, 214.

102 Mamers, O. Häda võidetuile. Stockholm, 1952, 175.

103 Ibid., 282.

104 Klimas, P. Lietuvos diplomatinèje tarnyboje 1919-1940 m. Vilnius, 1991, 158.

105 See Hough, W. J. H. The Annexation of the Baltic States And Its Effect On the Development of Law Prohibiting Forcible Seizure of Territory. - New York Law School Journal of International and Comparative Law, 1995, 6, 2, 430.

Ibid., 433. 
In August 1940 the Swiss government closed all its consulates in the Baltic states. Starting with January 1, 1941, it stopped its recognition of the Baltic diplomatic and trade representations in Switzerland while allowing these representatives to retain certain diplomatic privileges. It forbade them to participate in any kind of political activities in the country. All this meant, at least indirectly, the Swiss recognition of the incorporation of the Baltic states into the Soviet Union de facto. However, the Swiss government steadfastly refused to grant its de jure recognition of the incorporation. It also declined to surrender the Baltic gold to the Soviet Union.

After the incorporation of the Baltic states into the Soviet Union, the Control Commission of the League of Nations placed these states into a special category of its membership and allowed their representatives to stay in place. At the same time Sean Lester, the acting Secretary General of the League, avoided any official contacts and dealings with the Baltic diplomatic representatives. Soon Great Britain, keeping in mind its good relations with the Soviet Union, recommended the League to reject the efforts of these representatives to pay the membership fees of their respective countries. The League of Nations complied by returning the payments for the year 1943. The Baltic representations at the League of Nations continued functioning formally until the liquidation of the League in April 1946. In fact the Baltic representatives were prevented from taking part in the final General Assembly meeting because of the parliaments of all three Baltic states having voted in favor of their incorporation into Soviet Union and therefore no longer existed de facto nor de jure. Their assertion that the respective plebiscites had been rigged were rejected on the grounds of no real proof being available. ${ }^{107}$

The Swedish government took the Soviet invasion of the Baltic countries as a warning sign of the new Soviet attack against Finland. Sweden was also apprehensive that as a counterattack, Germany might occupy the island of Gothland. It was presumed that a war between Germany and the Soviet Union was unavoidable. For this reason the occupation of the Baltic states was assumed to be a temporary phenomenon. Rumors spread in Sweden that $\mathrm{OKH}^{108}$ had already prepared detailed plans for the military action against the Soviet Union. These unconfirmed tales also reached the Estonian government through its legation in Stockholm. ${ }^{109}$

At first the Estonian legation in Stockholm tried to conceal the real situation in the Baltic states, and to prevent disclosure of truthful information. For example, on June 12, two days before the ultimatum was given to Lithuania, Stockholms Tidningen published an article about the crisis in Lithuania, which spoke of the wish of the Soviet government to station half of a million soldiers into Balticum.

107 Ibid., 435-436; see also Made, V. Eesti ja Rahvasteliit. - In: Dissertationes Historiae Universitatis Tartuensis, 3. Tartu, 1999, 224-231; Jonušauskas, L. Likimo vedami, 66-67, 87.

108 Oberkommando des Heeres.

109 Laretei's report, June 20, 1940. - ERA, 957-17-5, 172; Ast's report, June 26, 1940. - BA, Karl Ast's arkiv; Wasastjerna's report, June 20, 1940. - UM, 5C/12. 
The Estonian press attaché Karl Ast attempted to prevent the publication of the named article. On June 14 in a dispatched report to Tallinn, Ast accused the Swedish government of the inability of restraining its press. ${ }^{110}$ But of course Ast did not act on his own. He had to follow the instructions received from the Estonian Foreign Ministry. When the Swedish press expressed indignation that the Soviets had occupied the Baltic states, and had demanded the formation of new governments, Heinrich Laretei, the Estonian envoy in Sotckholm, even as late as on July 12 claimed the legality of the new Soviet-established government. ${ }^{111}$ In early July, Nigol Andresen, the new Estonian Foreign Minister, had ordered Laretei and Ast to spread "peaceful and objective" information in Stockholm and to fight against any kind of "rumors". Andresen recommended letting the Swedish government know that the shipment of oil shale to Sweden will depend entirely on Sweden's political attitude and "objectivity". 12

On July 24, after the parliamentary elections in the Baltic States, Laretei's conscience awoke: he gave to the Swedish Minister of Justice, Karl Gustav Westman ${ }^{113}$, a note in which he implored that the changes carried out it Estonia through violence, coercion and deceit would not be recognised by the Swedish government. Laretei received an oral answer from Westman, stating that Sweden does not have any other alternative than to recognise the factual situation in Estonia. ${ }^{114}$ The note itself did not receive an official written answer. It can be understood that the collapse of the Western Allies had put Sweden into a difficult position, and that the Swedish government did not wish to incense the Soviet Union by viewing Germany as a defender of smaller states against the Soviet aggression. On August 16 in his speech at the Riksdag, Christian Günther, the Swedish Foreign Minister, discussing the Baltic question mentioned that the Swedish legations in the Baltic countries and the Baltic legations in Stockholm will be closed down on the request of the new rulers in these countries. But the former Foreign Minister Östen Undén declared that nobody believed that a voluntary unification of the Baltic states with the Soviet Union had taken place, instead the witnesses had observed a brutal conquest of three pygmy states by a superpower. ${ }^{115}$ Thus the views expressed by the members of government did not always coincide with those of politicians who stood outside the government. It should also be noted that at this time the Swedish government held discussions with the Soviet Union to conclude an advantageous tradeagreement while attempting to be compensated for the properties and investments belonging to the Swedish citizens and firms in the Baltic states.

\footnotetext{
110 ERA, 957-17-5, 167.

111 Laretei's report, July 13, 1940. - ERA, 957-14-689, 37-37p.

112 Andresen to Laretei, July 1, 1940. - ERA, 957-17-5, 171.

113 See also Carlgren, W. M. Swedish Foreign Policy during the Second World War. London, $1977,257$.

114 Laretei to Warma, August 21, 1940. - BA, Laretei, 1; Laretei, H. Saatuse mängukanniks, 211-212.

115 Carlgren, W. M. Rootsi ja Baltikum: maailmasõdadevahelisest ajast sõjajärgsete aastateni: ülevaade. Tallinn, 1995, 28.
} 
On August, 111940 the Swedish government presented a note to the Soviet Union about the financial interests of Sweden and some of its citizens in Lithuania, Latvia and Estonia. ${ }^{116}$ At this time the Swedish government calculated that the Soviet Union owed $35,000,000 \mathrm{Skr}$ to the Swedish government and to various firms, 5,000,000 Skr for different trade debts, and 30,000,000 Skr for nationalized plants, etc. that belonged to Swedish investors. On that last point the Swedish government strove to achieve "a principal agreement". To sweeten the deal the Swedes offered to the Soviet Union 100,000,000 Skr. Credit: 40,000,000 for building a plant for manufacturing rolling stock for the Soviet consumption and $60,000,000$ for purchasing the Swedish commodities and goods. The last point, however, was offered with a condition: this money became available to the Soviet Union only after the question of Swedish interests in the Baltic states had been taken care of. ${ }^{117}$ In the second half of August 1940, Erik Boheman, General Secretary of the Swedish Foreign Ministry, traveled to Moscow to discuss problems described above with the Soviet authorities. He told Molotov that the Swedish government will deliver the Baltic gold to the Soviets and that Sweden is convinced of the Soviet government's readiness to honor the Swedish interests and rights. ${ }^{118}$

The Swedish demands were discussed in the Politbureau. In response to the Swedish August 11 note, the Soviet government declared on October 11 that the properties and investments in question had already been confiscated by the Estonian, Latvian and Lithuanian governments respectively before the incorporation of these states into the Soviet Union, and for this reason the Soviet government was not responsible for the financial losses befallen on Sweden. At the same time the Soviet government alluded to the willingness of Estonian, Latvian and Lithuanian socialist republics to pay Sweden some compensation for the confiscated Swedish property. The actual amount of the compensation was left up to the Swedes to determine with an offer of the following payment possibilities: $10 \%$ of the total sum would be paid to Sweden in one year, $15 \%$ in three years, $20 \%$ in six years and $25 \%$ in 10 years. According to Molotov, with this offer the Soviet government had been very forthcoming indeed. ${ }^{119}$ According to Molotov with this offer the Soviet government was very obliged indeed. ${ }^{120}$ On November 6 , the Swedish government's note to the Soviets stated that because of the Soviet Union's prevalence in the Baltic States, it is responsible for the debts of the Baltic states to Sweden also according to the international laws. ${ }^{121}$ With this statement Sweden recognised the

116 Российский государственный архив социально-политической истории (RGASPI), 17-162-29, 129.

117 Memorandum by Molotov (Conversation with Assarsson), August 10, 1940. - ДВП, ХХІІІ, кн. первая, 498-499.

118 Memorandum by Molotov (Conversation with Boheman), August 19, 1940. - ДВП, ХХІІІ, кн. первая, 524-525.

119 RGASPI, 17-162-29, 166-167.

120 Memorandum by Molotov (Conversation with Assarsson), October 11, 1940. - ДВП, ХХІІІ, кн. первая, 663-665.

121 Dunsdorfs, E. The Baltic Dilemma. The case of the jure recognition by Australia of the incorporation of the Baltic States into the Soviet Union. New York, 1975, 123. 
incorporation of the Baltic states into the Soviet Union de jure. On May 30, 1941 Sweden and the Soviet Union signed the negotiated agreement, which determined and regulated the compensation for Swedish properties and investments in the Baltic region. The Soviet government pledged to pay within two years 20,000,000 Skr to Sweden and the Swedish government was obligated to deliver all Baltic gold reserves to the Soviet government. The Soviet government viewed this agreement as an official recognition of the Baltic states incorporation into the Soviet Union.

In fact, Sweden had viewed the independence of the Baltic states already in the 1920s and 1930s as a temporary phenomenon. Perhaps the assessment of a well-known Swedish expert of foreign policy, Wilhelm M. Carlgren, characterizes best the Swedish position in the matter: "In the summer of 1940 Sweden saw itself at the final stop, predicted long ago, although postponed repeatedly by the prevailing conjunction of circumstances in the Baltic region, and approved by all intermittent Swedish governments."122

Norway was occupied by the German forces in April-June 1940, but the Soviet government severed its diplomatic relations with the Norwegian exile government only in May 1941. For this reason the Norwegian exile government's policy with respect to the incorporation of the Baltic countries was benevolent. On August 24, 1940, the Norwegian envoy in Moscow announced in a note given to Molotov that yielding to the requests of the Soviet government, Norway had recalled all its representatives from the Baltic states. ${ }^{123}$

Denmark surrendered to Germany in April 1940. On July 24 August Koern, the Estonian representative in Copenhagen, submitted a protest note to the Danish Foreign Minister, Erik Scavenius, ${ }^{124}$ concordantly with similar action of Estonian legation in Stockholm. Scavenius did not understand on whose name Koern was protesting. Later, while preparing a summary of his activities in Denmark, Koern remembered that he had been impelled to admit to Scavenius that no government nor committee had authorized him to present the described protest note. Consequently, the Danish Foreign Ministry accepted Koern's protest as an expression of one individual's opinion, but with the consensus that if Koern had considered the issue properly, he would not have presented his note at all. ${ }^{125}$ Also Denmark was interested in collecting a payment from the Soviet Union for all the Danish properties and treasures invested in the Baltic countries. For example the Kunda cement plant in Estonia and the Liepajja oil refinery in Latvia belonged to the Danish investors. The discussion with the Soviets for resolving this problem commenced in September-October 1940. ${ }^{126}$

The Finnish governmental circles became agitated because of the revolutionary procedure used by the Soviet emissaries to remove the lawful governments in the

Carlgren, W. M. Rootsi ja Baltikum, 39.

Советско-норвежские отношения 1917-1955. Сборник документов. Москва, 1997, 302.

Foreign Minister, June 8, 1940-May 5, 1940.

Memorandum by Koern. Estonian legation and honorary consulate in Copenhagen. - BA, 3.

See Kyhn, P. Taani suhtumine Balti riikidesse aastail 1940-1950. - Akadeemia, 1996, 11, 2308-2309. 
Baltic states to be replaced with the new unlawful ones. ${ }^{127}$ However, in the Finnish press the "June-events" in Balticum were overshadowed by the events in Europe. The news media provided mainly stories about the situation in the Baltic states, and viewed Prime Minister Vares' government as Estonia's legal government. The Estonian envoy to Finland, Aleksander Warma, unlike other Estonian diplomatic representatives, did not deliver a written protest note to the Finnish government concerning the incorporation of Estonia into the Soviet Union during the critical period in July 1940. Warma stated in his memoirs that he had presented to the Finnish government a question about the status of Estonian legation in Helsinki, as Estonia was united with the Soviet Union. ${ }^{128}$ Finally, on August 7, after Estonia had been incorporated into the Soviet Union, Warma delivered a note of protest, similar to those of other Estonia diplomatic representatives in other countries, to the Finnish Foreign Minister Rolf Witting. On receiving the note, the Finnish Foreign Ministry announced that the note would not be answered. ${ }^{129}$

Events in the Baltic states activated the Finnish communists and left-wingers, who had rallied around the Finnish-Soviet Society of Peace and Friendship. ${ }^{130}$ At the end of July and in the beginning of August the society organized antigovernment demonstrations in a number of cities, and called upon people to set up barricades. ${ }^{131}$ At the same time the Soviet Union presented the Finnish government with diverse demands of political and economic nature. The situation became hostile and threatening to such an extent that on August 5 Marshal C. G. Mannerheim demanded that the government carry out partial mobilization. The Finnish government disagreed with Mannerheim.

On July 31, 1940 Reinhold Svento, one of the leaders of the Finnish Social Democratic Party, claimed in an editorial of Suomen Sosialidemokraatti: "Nations that had depended on the Great Powers were not politically able to deal with the true national freedom, but on the contrary were compelled to suffer under the dictatorial governments of their own countries - so that the choice between a foreign and a home-grown repression became insignificantly small." Svento's opinion falls into same category with that of the Finnish envoy to Latvia, Eduard Palin, who evaluated Ulmanis régime in Latvia. Palin recorded his observations after the incorporation of the Baltic states by the Soviet Union, in September 1940. Of course, the evaluation of the situation in the Baltic states by Palin, a man of Swedish origin, could be thought of as a hindsight wisdom only. But even if

127 See Warma's report, June 25, 1940. - ERA, 957-17-5, 40.

Warma, A. Diplomaadi kroonika. Ülestähendusi ja dokumente aastatest 1938-1944. Lund, 1971, 135.

129 Baaside lepingust anneksioonini, 205-206; see also Eesti Vabariigi saadiku noot Soome välisministrile. Komment. S. Zetterberg. - Looming, 1989, 4, 512-513.

130 Suomen-Neuvostoliiton Rauhan ja Ystävyyden Seura.

131 EK VALPO, I. Information of the Finnish Political Police, June 24 and September 12, 1940.KA, 12; see also Krosby, H. P. Nikkeli-diplomatiaa Petsamossa 1940-1941. Helsinki, 1966, $79-80$. 
Svento's interpretation were considered biased because of his obvious left-leaning tendencies, Palin's views were clearly not Soviet-friendly. Palin, describing life and prevailing political circumstances in Latvia, writes: "Those who did not belong to the clique around the government had no influence on the course of events. Ulmanis had assembled a small group of servile advisers with whose support he governed the country in an absolutely autocratic manner. Consequently, he increasingly isolated himself from his nation, alienated his people and put aside their economic visions, wishes and goals. Without saying, it is clear where it all eventually led to - a total disappointment and a sense of disgust about everything took hold of the population. When Moscow began its offensive against the Baltic states, the Russians found that Latvia was internally split, that its people were dissatisfied, that the government was untrustworthy - in short a political system that nobody was willing to defend. Of course, it can be argued that accounting for Soviet predominance and the prevailing international situation, the fate of Latvia would have in any case been the same. Nevertheless, like many of my colleagues, I too could not avoid thinking that Latvia would not have surrendened without any resistance, as it did, if it had possessed a free democratic government. Had Latvia been free of its dated dictatorial government, but instead had been on the way to a healthy democratic political system in which each citizen would be able to influence all aspects of the government, and by being aware of his responsibilities and duties to fight for the common interests, Latvia may not have surrendered in the manner it did, and its fate may have been somewhat different from the one that fell to its lot." 132 Palin's understanding of the reasons for Latvian collapse in 1940 is even more pertinent in case of Lithuania, and only slightly less apt for Estonia: the name of Ulmanis could easily be replaced with those of Päts or Smetona.

In Finland the interests of Germany and Great Britain intersected. Considering the British as possible future allies, and foreseeing the resultant British public opinion in the summer of 1940, the Soviet Union did not dare to manipulate Finland in the same manner it had done in the case of the Baltic countries. Also Germany, keeping in mind the security of Scandinavia, could not agree with the repetition of the Baltic events in Finland.

But it is not correct to assume that only the coercion from Germany and the Soviet Union determined the attitude of the Scandinavian countries toward the incorporation of the Baltic states. When Wehrmacht and the Red Army had occupied Poland, the Scandinavian states had not requested closing the Polish legations and consulates. The Polish diplomatic representatives continued their work in Oslo, Stockholm, Copenhagen and Helsinki regardless of repeated demands by the Germans and the Soviets for the recognition of the accomplished conquest of Poland. The governments of the Scandinavian states did not doubt that Polish agencies represented the legal Polish government of General Władislaw Sikorsky, established in Anger, France. Only after Wehrmacht occupied Denmark, the Danish

132 Memorandum by Palin, September 11, 1940. Reminiscences from Latvia, August 1939-August 1940, II. - UM, 7. 
Foreign Minister Scavenius announced that the Polish government no longer existed. Finland did not sever its diplomatic relations with Poland until June 1941, one day before entering war on the side of Germany. The Swedish and Norwegian governments did not decline granting recognition to the Polish government in exile. ${ }^{133}$ It must be asked where then is the "difficult situation", with which some historians justify the attitude of Sweden and Finland toward the incorporation of the Baltic states? In this case an entirely different aspect of circumstances has to be considered, decisive in the shaping of the public opinion on the matter. Thus, the silent surrender of the Baltic states with the concurrence of their governmental authorities not only cleared the way for the approaching incorporation, but essentially influenced the attitudes of a number of European states, among others Sweden and Finland. Whereas, contrariwise, the military resistance of Poland to the German attack removed the possibility of treating the occupation of Poland as a voluntary unification with the conqueror state. This, hopefully, will explain the position of Sweden and Finland toward the Baltic countries - victims of the Soviet Union.

The United States of America followed the policy of neutrality considering the fighting as well as the political situation in Europe and observed just as keenly the goings-on in the Far East. The Soviet-USA relations tensed notably after the commencement of military actions in Europe and the appearance of the Soviet expansionist foreign policy in Eastern Europe - the incorporation of the eastern part of Poland and the start of the Winter War against Finland. But the American government did not react at all to the disturbing events taking place in SeptemberOctober 1939 in the Baltic region. In fact, when a Soviet diplomatic representative after the conclusion of the Estonian-Soviet mutual assistance pact tried to determine the reaction of the American president as well as the Secretary of State, he only received answers formulated in meaningless generalities: "No comment", "We have to study the matter in detail", "The situation is under consideration", etc. ${ }^{134}$ The Baltic question did not become an issue until June-July 1940 when the Baltic states had clearly been occupied by the Soviet Union, and soon incorporated into it. As a result, the tension of the Soviet-USA relations increased.

Like agents in other countries, also the Baltic foreign representatives in the United States initially assumed a hesitant position, because the future of the Baltic states was unclear even to the puppet governments of the states in question, formed under the direction of the Soviet potentates. However, the picture clarified considerably during the preparations for the parliamentary "elections" in the Baltic States, and opened the floodgates of opposition to the Soviet aggression in the United States. In this case Lithuanians acted more energetically than other Balts.

133 See Koszel, B. The attitude of the Scandinavian countries to Nazi Germany's war preparations and its aggression on Poland. - In: The Baltic and the Outbreak of the Second World War. Ed. J. Hiden, T. Lane. Cambridge University Press, 1992, 132-140.

134 Tshuvahhin's telegram, September 30, 1939. Документы внешней политики СССР 1939, XXII, кн. вторая. 1 сентября-31 декабря 1939 г. Москва, 1992, 145; see also Mayers, D. The Ambassadors and America's Soviet Policy. Oxford University Press, 1995, 127-128. 
On June 29 a delegation of Lithuanian-Americans met with the Lithuanian envoy in Washington, Povilas Žadeikis. When the delegation proposed strong opposition to the occupation of Lithuania, and protested the actions of Lithuanian diplomats and consular officials who had established contacts with the new communist government in Kaunas, it seemed that Žadeikis declined to take a firm stand against the government of Justas Paleckis. The participants of the meeting agreed, however, to oppose the regime introduced by the Soviets in Lithuania. ${ }^{135}$ Thus Žadeikis became the first Baltic diplomat who dared to protest against the Soviet incorporation, and demonstrate the illegality of the new régimes in the Baltic States. In a July 13 memorandum to Cordell Hull, the Secretary of State, Žadeikis assured that the new Lithuanian parliamentary elections did not reflect the free will of the Lithuanian people. ${ }^{136}$

Estonia did not have a legation in Washington. In New York, however, a general consulate existed under the direction of Johannes Kaiv. On July 17 Kaiv presented a note of protest to the Secretary of State asking the United States to consider the Soviet invasion of Estonian territories as a military attack, and as a violation of the international laws and existing valid treaties. On that day the new Baltic parliaments had not as yet expressed their wish to become a part of the Soviet Union. Kaiv understood that the purpose for elections, held under conditions of occupation, was to create a "legitimate foundation" for the incorporation of the Baltic states into the Soviet Union. In the July 23 note to the State Department Kaiv asked for non-recognition of Estonia's annexation. Žadeikis and the Latvian Envoy Alfrēds Bīlmanis presented similar notes on August 3 and 6, respectively. ${ }^{137}$ The activities of Kaiv and Žadeikis brought the hoped-for results: on July 23 the State Department officially denounced the incorporation of the Baltic countries. Sumner Welles, Undersecretary of State, declared that the people of the United States are opposed to the rapacious behavior of the Soviet Union, carried out with force or with threat of force, in cases when a stronger state meddles in the internal affairs of weaker ones. This denouncement was also published in the press. ${ }^{138}$

The American position was also influenced by the financial and economic interests of the United States, particularly in the Baltic gold held in the American banks. Already on July 13 the Central Banks of Estonia, Latvia and Lithuania had informed at the request of Soviet authorities the Federal Reserve Bank of New York, that the Estonian, Latvian and Lithuanian gold has been sold to the Central Bank of the Soviet Union. ${ }^{139}$ This was, of course, a simple lie offered for the purpose of getting the Baltic gold into Soviet hands.

135 Vitas, R. A. The United States and Lithuania. The Stimson Doctrine of Nonrecognition. New York, 1990, 32.

136 Foreign Relations of the United States (FRUS). Diplomatic Papers 1940, I, General. U.S. Department of State, Washington, D.C., 1959, 387.

137 FRUS, 1940, I, 400, 406-407.

138 FRUS, 1940, I, 401-402.

139 The note of the Soviet Government, July 20, 1940. Советско-Американские отношения 1939-1945. Документы. Россия XX век. Москва, 2004, 76. 
The government of the United States was faced with a dilemma whether its reaction to the Baltic question should be similar in content to the case of Poland and Czechoslovakia being occupied by Germany, or should it follow a different political path. Hitherto, the United States had tried to appear as a defender of small countries and democracy. On July 15, just one month after the occupation of the Baltic states, Loy Wesley Henderson, the Deputy Director of the European Section of the State department, presented a memorandum to the Undersecretary of State. In it Henderson addressed the ambiguous issue about the United States combating Hitler while ignoring Stalin's aggressive activities, thus displaying confusion and relative unfairness in its dealings with the Soviet Union and Germany. ${ }^{140}$ This memorandum also touched upon the United States financial interests in the Baltic states: "The value of property and capital invested by the American citizens and corporations in the Baltic States comes to 12-13,000,000 dollars." Henderson assumed that if the Baltic states were absorbed by the Soviet Union, not one penny would be returned to the United States. ${ }^{141}$ On the same day President Roosevelt issued Order I8484 to freeze all Baltic treasures in the United States. ${ }^{142}$ Based on President Roosevelt's Order I8484, the Federal Reserve Bank of New York declined to hand over the Baltic gold to the Soviet Union when it requested the gold's transfer to the Soviet State Bank. This occasion, as well as the American publicly expressed reproach concerning the Baltic problem, irritated the Soviets no end, and therefore required a proper answer. On July 20 the Soviet government presented a note to the United States government demanding an immediate transfer of the Baltic gold to the Soviet State Bank, while stressing that no laws and regulations exist in the American jurisprudence that could restrain the Soviet Union from receiving the gold sold to it by the Baltic states. ${ }^{143}$

The political positions declared by the United States, provoked considerable interest in Moscow and therefore did not remain unanswered. On July 26 Pravda declared, referring to previous authoritarian régimes in the Baltic States, that the United States government does not have any reason to worry about the legality of elections in the Baltic states, since all three Parliaments, chosen by the unprecedented majority in the freest elections ever in the Balticum, had expressed an unanimous wish to become a part of the Soviet Union. Pravda's article was followed by a note from Konstantin Umanski, the Soviet ambassador in Washington, which proclaimed that the United States' July 23 statement, concerning the incorporation of the Baltic states, offends the Soviet government in the extreme, and is misleading about the factual circumstances. According to Umanski, the American people should be happy about the actions of the Soviet

\footnotetext{
140 FRUS, 1940, I, 390.

141 Ibid., 391.

142 Vitas, R. A. The United States and Lithuania. The Stimson Doctrine of Nonrecognition. New York, 1990, 3.

143 The note of the Soviet Government, July 20, 1940. Советско-Американские отношения 1939-1945, 76.
} 
Union, since it destroyed the seeds of fascism, and at the same time protected Baltic people against their worst enemies. At the beginning of August Umanski continued his harangue. He deigned not to understand why the United States government strongly opposed the progress of democracy in Eastern Europe. Subsequently he declared the Baltic States an area having belonged to Russia already in ancient times. ${ }^{144}$

On August 11 Molotov informed the United States Moscow embassy that the United States must close all its legations and consulates in the Baltic states by August $25 .{ }^{145}$ On the next day, on August 12, the American government responded to Molotov's order and to the issue of Baltic gold. This memorandum of the State Department referred to the Baltic states as occupied countries, and stated that because the request for the Baltic gold had been presented simultaneously with the Soviet military occupation of the named countries. ${ }^{146}$ American refusal to release the gold to the Soviet Union is fully justified. Alluding to the Soviet claim that by refusing to hand over the Baltic gold the American government had violated the elementary principles of international law, the memorandum pointed out that the American government had reacted in similar manner on the occasion of other military occupations by freezing the victims' wealth located on the American soil. Of course, the unexpressed reason for the American blunt response was the fear that the Soviet Union will start using the Baltic gold in their own interest, perhaps for the subversive activities in the United States. The issue of closing American legations and consulates in the occupied Baltic countries was dealt with in a separate note from the American embassy in Moscow, which declared that the American government did not recognise the legality of laws used as the basis for the Soviet claim and therefore in closing these missions as requested, preserves all property rights of the buildings involved. ${ }^{147}$ At the time there were American politicians who were doubtful about the wisdom of holding onto the Baltic gold as well as the inciting policies of the United States. It was feared that the American brusque action could unexpectedly aggravate the possibility of bringing the Soviet Union to the Western allies' camp.

At the Soviet Commissariat of Foreign Affairs it was determined that the Soviet government should pass on to the American Moscow embassy the Soviet refusal to accept their August 12 note, since it asserts that Soviet military forces had occupied the Baltic states. In fact, a rather abrupt answer, indeed a protest was being prepared in answer to the embassy's August 14 note, which declared

144 Memorandum by Henderson, August 15, 1940. Foreign Relations of the United States. Diplomatic Papers 1940, III. The British Commonwealth. The Soviet Union. The Near East and Africa. Department of State. Washington, 1958, 371.

145 Note by Molotov to the United States Embassy, August 11, 1940. Советско-Американские отношения 1939-1945, 79-80.

146 Memorandum by the Goverment of the United States, August 12, 1940. Советско-Американские отношения 1939-1945, 80-83.

147 Memorandum by the Embassy of the United States in Moscow, August 14, 1940. СоветскоАмериканские отношения 1939-1945, 84.

148 Blum, J. M. From the Morgenthau Diaries, 327-328. 
that the Soviet government could accept a note which did not comprehend or recognise the right of the Baltic people to make their own decisions concerning their fate. This response also stressed the fact that USA in the 1920-1922 period had viewed the Baltic states as a former part of the Russian empire, and had considered their becoming independent undesirable for both the Russian and also for Estonian, Latvian and Lithuanian populations. ${ }^{149}$ In fact, the United States had refused to recognise the new independent small states de jure.

Thus the United States became the only country to defend the Baltic states: without the governments of these states requesting such an action, and was the only government to express a straightforward view about the activities of the Soviet Union. The basis for the described reaction was the so-called Stimson doctrine: in September 1932 the Secretary of State Henry Stimson had delivered identical notes to Japan and China, indicating that the United States government will recognise no territorial claims based on military conquests or on the agreements thrust upon the defeated party by force or by the threat of force. ${ }^{150}$ Thus the United States continued to refuse recognizing any territorial modifications, agreements and treaties that had been established through the application of force. But since the Stimson doctrine was mainly a statement of moral support, no follow-up steps were taken to stop the aggression in the Balticum. It has to be kept in mind that the United States was an economic superpower, who could afford to express its opinion freely. The issue was influenced also by the fact that Roosevelt was a presidential candidate for the third term, and therefore interested in the voting power of all Baltic-Americans, by estimation about 500,000-600,000 souls. ${ }^{151}$ Roosevelt, when meeting the Lithuanian voters, had promised them not to recognise the incorporation of the Baltic States into the Soviet Union. All in all, the declaration by the United States government that illegal actions do not result in legal rights to territories and power, remained only a moral principle.

In conclusion it can be stated that the American government responded rationally to the Baltic question with three concrete steps: first, it publicly protested the occupation of the Baltic region by the Soviet military forces and refused to recognise the incorporation of the Baltic states; second, it refused to hand over the Baltic gold held by USA, and the Baltic merchant ships docked in the USA ports to the Soviet Union as demanded; and third, it refused to close the Estonian, Latvian and Lithuanian diplomatic missions in the United States as requested by the Soviet Union. Thus the American government condemned the Soviet incorporation of the Baltic states and continued recognizing, as well as financing, the Baltic diplomatic missions. At the same time Washington announced that it will not recognise any of the Baltic exile governments appearing on the scene, because according to the American legal norms an exile government should be in

149 Project of the Commissariat of the Foreign Affairs, August 16, 1940. Советско-Американские отношения 1939-1945, 85-86.

150 Ibid., 3.

151 About the Lithuanian emigration to the United States see Эйдинтас А. Литовская эмиграция в страны Северной и Южной Америки в 1868-1940 гг. Вильнюс, 1989. 
an open military struggle with the country that has occupied the state from which the exile government has fled. ${ }^{152}$ This policy of the United States has stayed in force also in the following years. The apparent prudence of US government regarding the exile governments was supported by some weighty reasons. First, the United States was interested in stopping the Japanese expansion in the Far East, foreseeing in the Soviet Union an influential ally against it. Indeed, in July 1940 President Roosevelt and Henry Morgenthau, the Secretary of Treasury, raised the question of concluding an anti-Japanese Triple Pact between the United States, China and the Soviet Union, according to which USA would provide necessary credits to China for purchasing war materials from the Soviet Union. ${ }^{153}$ With this action the American president not only hoped to upgrade the fighting capabilities of the Chinese forces, but also to prevent Soviet Union's withdrawal from the involvement in the Far East, at the same time preventing the normalisation of relations between Japan and the Soviet Union. The last possibility was particularly abhorrent to the Americans, because it would strengthen Japan's position in the region. Notably the described plan concerning Japan was entirely antidotal to the American Baltic policy, that also had been initiated by the Treasury Department.

On September 20 Morgenthau proposed the above described Triple Pact to the Soviet government, which initially announced that it would be willing to start assisting China as the only anti-imperialist country around, but later considered handling the proposed program through the Soviet-China trade channels unsuitable. ${ }^{154}$ Consequently already on September 26 Laurence Steinhardt, the American ambassador in Moscow, informed Molotov that "the United States wishes to conduct concrete discussions about the improvement of mutual relations with the Soviet Union". While referring to the issue of Baltic gold, the ambassador no longer mentioned the term "occupation" but instead called American refusal to transfer the gold to the Soviet Union a "financial procedure" pre-determined by the liabilities of the Baltic states to the U.S. institutions: the debts of Estonia at 16,500,000, of Latvia at 7,000,000 and of Lithuania at 6,000,000 dollars. ${ }^{155}$

The conclusion and signing of the Triple Pact between Germany, Italy and Japan on September 27 in Berlin was interpreted by Washington as a devastating blow to the American Far East foreign policy. ${ }^{156}$ From this time on the U.S. government started to talk about "abandoning idealism" and "turning toward realism". Consequently, Washington commenced explaining its refusal to give up the Baltic gold in different terms, utilizing political arguments to the Soviet Union. Now Americans switched to the financial reasoning by claiming that the former independent Baltic states owed the United States considerable amounts of money and the gold reserves held by the American banks were needed to cover these debts.

152 See Jonušauskas, L. Likimo vedami, 54, 124.

153

Blum, J. M. From the Morgenthau Diaries, 347.

Ibid., 359-360. Molotov's telegram, September 25, 1940. - ДВП, ХХІІІ, кн. первая, 624.

Memorandum by Molotov, September 26, 1940. Советско-Американские отношения 19391945, 93-98.

156 Memorandum by Vyshinski, October 29, 1940. - ДВП, ХХІІІ, кн. первая, 717-718. 
In a further effort to appease the Soviet Union, it was told that USA did not require any more repayments of loans and investments made by American individuals and firms in the Baltic States. ${ }^{157}$ This benevolent attitude of the U.S. government was caused by its interest in drawing the Soviet Union into the net of the American Far East policy. On the other hand, Moscow's preconditions for improving relations between the two countries, the hushing of the official America's as well as press's negative commentary in the Baltic question - the solving of Baltic gold and merchant shipping problems - were certainly influential.

In the mind of American leadership the Triple Pact of Axis powers was geared not only against the United States and Great Britain but also against the Soviet Union. Consequently the American government revitalized its efforts to come to terms with the Soviet Union, even by using the help of Marshal Chiang Kai Chek, but regrettably without expected positive outcome. ${ }^{158}$ In fact, the Soviet government was more interested in normalizing its relations with Japan than becoming involved in conspiracies or alliances against it. For this reason it behaved particularly carefully with respect to the U.S. government and its political intentions. For all above described reasons the American government continued to make concessions to the Soviet Union. For example in January 1941 it informed the Soviet government that the so-called "moral embargo" enacted on December 2, 1939 will be lifted in case of the Soviet Union. ${ }^{159}$

The commencement of the Soviet-German war in June 1941 brought a radical change in the relationship of the two countries. Already in the first days of the war the State Department declared that the American government is ready to offer aid to the victimized Soviet Union. This improvement in mutual relations was primarily noticeable in the economic field, but also in the softened American stand with respect to the Baltic question. In fact, in discussions with Molotov in May 1942, Roosevelt stated that in taking into account the American public opinion, a suitable moment had to be chosen for the recognition of Soviet western borders. According to Roosevelt this moment had not as yet arrived. ${ }^{160}$

\section{CONCLUSIONS}

The Baltic states were unlawfully incorporated into the Soviet Union in the summer of 1940. Baltic people did not concur with this move and consequently throughout the following years conveyed their opposition in various forms to the accomplished fact. The attitude of democratic states toward the absorption of the

157 Molotov's telegram, September 27, 1940. - ДВП, XXIII, кн. первая, 633.

158 Blum, J. M. Roosevelt and Morgenthau. Boston, 1970, 399-400; see also Memorandum by Lozovski, October 1, 1940 and Umanski's telegram, October 18, 1940. - ДВП, ХХІІІ, кн. первая, 643, 691-693.

159 See Umanski's telegram, October 24, 1940. - ДВП, ХХІІІ, кн. первая, 708-710.

160 Ржешевский О. А. Война и дипломатия, 76-77, 165. 
Baltic states by the Soviet Union, except for the United States of America, and regardless of the tireless effort of the Baltic diplomats and political representatives in the free world, had basically remained indecisive. Great Britain was prevented from seeing the light by its hope to bring the Soviet Union into the Allied Powers' camp. Later, after the start of Soviet-German war, Great Britain without any compunction recognised the incorporation of the Baltic states into the Soviet Union de facto, while the Netherlands and Sweden did this de jure. In the fall of 1940 also the United States, hoping to draw the Soviet Union into an Anti-Axis military alliance against Japan, softened its originally stiff stand against the aggressive Soviet Union in the Baltic situation. With the outbreak of war between Germany and the Soviet Union, the Western allies increasingly considered the good relations with the Soviet Union a priority over the Baltic question with all its thorny aspects, and therefore tried to avoid any conflicts with Moscow in the matter. By August 1940 all countries having had diplomatic and trade relations with the former independent Baltic states, had conceded to the demands of the Soviet Union in closing down their diplomatic missions in the Baltic states. Some of these countries preserved a few diplomatic privileges for the now exiled former diplomats under restricted conditions. Latvian and Lithuanian refugees never established exile governments. The Estonian exile government, set up in 1953, never received the expected recognition from anybody. The succumbing of Eastern European countries to the control of the Soviet Union at the end of the Second World War split Europe into two hostile camps for the next 45 years. During this period the non-recognition policies concerning the incorporation of the Baltic states into the Soviet Union became eventually one of the important strategic conceptions in the so-called Cold War. At this time most of the democratic states refused to recognise the incorporation of the Baltic states de jure. Nevertheless, the whole matter seemed to be more symbolic than real, and therefore rather meaningless. James T. McHug and James S. Pacy in their research "Diplomats without a Country: Baltic Diplomacy, International Law and the Cold War", conclude after analyzing international law during the period between the two great wars, that after losing their independence in 1940 no reason existed for the survival of Baltic diplomatic representations, and none of the Baltic diplomats, escaped to the free Western World stood for their states, but represented only the idea of a country and the meaning of their respective nations. ${ }^{161}$

\section{ACKNOWLEDGEMENT}

The research was financially supported by the Estonian Science Foundation (grant no 2905, 3817, 5095). My special thanks go to translators Eino and Maia Saaremaa in the United States of America.

161 McHug, J. T., Pacy, J. S. Diplomats Without a Country. Baltic Diplomacy, International Law, and the Cold War. Greenwood Press, 2001, 152. 


\title{
RAHVUSVAHELINE REAKTSIOON BALTI RIIKIDE INKORPOREERIMISELE 1940. AASTA SUVEL JA JÄRGNEVATEL AASTATEL
}

\author{
Magnus ILMJÄRV
}

Seni ilmunud kirjanduses pole välisriikide reaktsioon Balti riikide okupeerimisele ning inkorporeerimisele 1940. aasta suvel ja Balti küsimusele II maailmasõja aastail leidnud piisavat käsitlemist. Artiklis on kasutatud ka Vene arhiivide materjale ja Venemaal ilmunud kirjandust. Artikli esimeses osas vaadeldakse pärast Nõukogude Liidu ultimaatumeid Eestis, Lätis ja Leedus moodustatud "juunivalitsuse" välispoliitikat. Artikli teises osas on uurimise objektiks välisriikide suhtumine Nõukogude Liidu okupatsiooni ja inkorporeerimisse.

Punaarmee okupeeris Leedu, Läti ja Eesti ilma sõjategevuseta. Kõrvaldanud sõjalist jõudu kasutades Balti riikide valitsused, rikkus Nõukogude Liit Balti riikidega sõlmitud vastastikuse abistamise lepingut. Teisalt aga lõi see, et Balti riikide valitsused olid sõlminud 1939. aasta sügisel vastastikuse abistamise lepingud ja et nad võtsid 1940. aasta juunis häält tegemata vastu Nõukogude valitsuse ultimaatumi, rahvusvahelise õiguse seisukohalt komplitseeritud situatsiooni. 1907. aasta Haagi konventsiooni regulatsiooni 42. artikli kohaselt loeti okupatsiooniks võõra riigi või selle osa hõivamist teise riigi relvajõududega. Okupatsioon loeti aga teostunuks siis, kui territoorium oli läinud okupeeriva riigi sõjaväe võimu alla ja seal oli moodustatud ning hakanud toimima sõjaväeline okupatsioonirežiim. 1907. aasta Haagi konventsioon ei öelnud midagi juhtude kohta, kus okupeerija ja okupeeritav leppisid kokku okupatsiooni maksmapaneku küsimuses. Kõigi kolme Balti riigi puhul seda tehti: kolme riigi seadusliku riigivõimu esindajad ei lükanud tagasi ultimaatumites sisalduvaid süüdistusi, need võeti tingimusteta ja protestimata vastu. Avalikkusele teatati, et tegemist ei ole okupatsiooniga, rahvast ja maailma kutsuti üles vaatlema Punaarmeed kui sõbraliku liitlase armeed, riigivõimult volitused saanud sõjalised esindajad andsid allkirja protokollidele, millega Nõukogude Liit sai nõusoleku territoorium okupeerida. Ka pärast 17. juunit 1940 deklareerisid Eesti, Läti ja Leedu nn juunivalitsused ning välisministeeriumid oma rahvale ja maailmale, et uus valitsus moodustati konstitutsioonilises korras. Pidevalt rõhutati, et iseseisvus säilib ja muutub ainult maa välispoliitiline orientatsioon - orienteerutakse üksnes Nõukogude Liidule. Nii tegutsedes desinformeeriti oma rahvast ja maailma. Välisriikide raadiojaamad ja ajakirjandus kordasid sõnasõnalt neid avaldusi ja õigustasid Balti riikide valitsustele tuginedes Nõukogude Liidu agressiooni. Kolme riigi valitsuste ja välisteenistuste tegevusel oli oluline roll selles, kuidas hindas maailm järgnevalt Balti riikides toimuvat.

Balti riigid inkorporeeriti 1940. aastal õigusvastaselt Nõukogude Liitu. Balti rahvad ei nõustunud sellega ja osutasid Nõukogude Liidule mitmesuguses vormis vastupanu. Demokraatiate suhtumine Balti riikide inkorporeerimisse, välja arvatud Ameerika Ühendriigid, jäi Balti riikide saadikute omaalgatuslikele protesti- 
nootidele vaatamata ebaselgeks. Inglismaad hoidis seisukohavõtust tagasi lootus, et Nõukogude Liidust võib saada liitlane Saksamaa-vastases sõjas. Hiljem tunnistas Inglismaa Balti riikide inkorporeerimist de facto. Holland ja Rootsi tunnistasid Balti riikide annekteerimist de jure. Kuid ka Ühendriigid, lootes, et Nõukogude Liidust võib saada mingi vastujõud Jaapani ekspansioonile Kaug-Idas, leevendasid 1940. aasta sügisel oma suhtumist inkorporeerimisse. Saksa-Nõukogude sõja puhkedes hakkasid lääneliitlased üha rohkem pidama prioriteediks häid suhteid Nõukogude Liiduga ja püüdsid Balti küsimuses vältida konflikti Moskvaga. Enamik Balti riikidega diplomaatilistes suhetes olnud riikidest tuli 1940. aasta augustis vastu Nõukogude valitsuse nõudmistele ja lõpetas Balti esinduste tegevuse. Mõni riik säilitas endiste Balti riikide diplomaatidele nende diplomaatilised privileegid. Leedu ja Läti eksiilvalitsust ei loodud kunagi. 1953. aastal loodud Eesti eksiilvalitsusi aga ei nõustunud tunnustama ükski riik.

Ida-Euroopa langemine Teise maailmasõja lõppedes Nõukogude Liidu mõjusfääri tõi kaasa Euroopa poliitilise ja sõjalise lõhestatuse 45 aastaks. Pärast sõda sai Balti küsimus ehk nn inkorporeerimise mittetunnustamise poliitika üheks külma sõja strateegia komponendiks. Enamik Lääneriikidest ei tunnustanud kunagi Balti riikide faktilist inkorporeerimist. Kuid see kõik oli esmajoones sümboolne. 